\title{
New insights in osteogenic differentiation revealed by mass spectrometric assessment of phosphorylated substrates in murine skin mesenchymal cells
}

\author{
Erik Halcsik', Maria Fernanda Forni ${ }^{1}$, Andre Fujita ${ }^{2}$, Thiago Verano-Braga ${ }^{3}$, Ole Nørregaard Jensen ${ }^{3}$
} and Mari Cleide Sogayar ${ }^{1 *}$

\begin{abstract}
Background: Bone fractures and loss represent significant costs for the public health system and often affect the patients quality of life, therefore, understanding the molecular basis for bone regeneration is essential. Cytokines, such as IL-6, IL-10 and TNFa, secreted by inflammatory cells at the lesion site, at the very beginning of the repair process, act as chemotactic factors for mesenchymal stem cells, which proliferate and differentiate into osteoblasts through the autocrine and paracrine action of bone morphogenetic proteins (BMPs), mainly BMP-2. Although it is known that BMP-2 binds to ActRI/BMPR and activates the SMAD 1/5/8 downstream effectors, little is known about the intracellular mechanisms participating in osteoblastic differentiation. We assessed differences in the phosphorylation status of different cellular proteins upon BMP-2 osteogenic induction of isolated murine skin mesenchymal stem cells using Triplex Stable Isotope Dimethyl Labeling coupled with LC/MS.
\end{abstract}

Results: From 150 ug of starting material, 2,264 proteins were identified and quantified at five different time points, 235 of which are differentially phosphorylated. Kinase motif analysis showed that several substrates display phosphorylation sites for Casein Kinase, p38, CDK and JNK. Gene ontology analysis showed an increase in biological processes related with signaling and differentiation at early time points after BMP2 induction. Moreover, proteins involved in cytoskeleton rearrangement, Wht and Ras pathways were found to be differentially phosphorylated during all timepoints studied.

Conclusions: Taken together, these data, allow new insights on the intracellular substrates which are phosphorylated early on during differentiation to BMP2-driven osteoblastic differentiation of skin-derived mesenchymal stem cells.

\section{Background}

Fractures and bone loss impose high costs for the Public Healthcare System. Furthermore, delayed-healing fractures lead to recurrence lesion, with quality of life's loss and increased patient morbidity. In the normal healing process, the bone tissue function is regenerated through endochondral ossification and intramembranous ossification, which often occur at same time at the lesion site, under the

\footnotetext{
* Correspondence: mcsoga@iq.usp.br

${ }^{1}$ Chemistry Institute, Department of Biochemistry, Cell and Molecular Therapy Center (NUCEL/NETCEM), School of Medicine, University of São Paulo, São Paulo 05508-000, SP, Brazil

Full list of author information is available at the end of the article
}

influence of inflammatory agents, such as IL1, IL6 and TNF- $\alpha[1,2]$, which induce migration and proliferation of periosteum mesenchymal stem cells. These cells differentiate into osteoblasts, the major step in the regenerative process. However, during the individual's lifetime, both the availability and the ability of these cells to differentiate diminish, leading to incomplete or total absence of tissue regeneration at the fracture site. Although physiological details are well understood, the molecular aspects of the differentiation process occurring in the osteoblast lineage from adjacent mesenchymal cells remain unclear.

To address this issue, autologous Mesenchymal Stem Cells (MSCs) have been utilized, improving the bone 
tissue regeneration capability and leading to reduction of both total costs and hospitalization period, with a significant decrease in lesion recurrence [3]. These cells gained importance in Regenerative Medicine, due to their ability to differentiate into chondrocytes, adipocytes and osteoblasts, and facility with which they may be isolated from several organs, among which is the skin. Due to its function of protecting from exposure to deleterious agents, such as UV light, physical injuries and pathogens, the skin displays a high cell proliferation rate, which is maintained by the self-renewal and differentiation capabilities of the several stem cell populations present in skin niches [4]. These cells are of particular interest, since they may be easily isolated from the skin, in reasonable amounts, being highly suitable for bone healing and repair [5].

Although it is known that osteogenic differentiation in MSCs is initiated through activation of canonical pathways such as SMAD (Sma and Mothers Against Decapentaplegic) proteins, the possible protein interactions with other pathways which may influence cell differentiation remain elusive. The activation of different downstream signaling cascade pathways, includes Hedgehog, Wnt, PTHr-P and BMPs, which, in turn, activate the main transcription factors related to osteogenesis through their respective pathways [1]. Smads, for example, may be positively or negatively regulated by phosphorylation of different residues, leading to activation or suppression of the BMPinitiated signal [6]. These kinase pathways, in turn, activate downstream effectors in the cytoplasm and nucleus by phosphorylating a network of substracts. Since the study of protein phosphorylation depends mainly on phosphospecific antibodies and the utilization of radioisotopes, identification of novel phosphorylation sites has been a laborious task. However, the development of mass spectrometry techniques by detection of inorganic phosphate neutral loss through CID (collision induced dissociation), originated from phosphoserine, phosphotyrosine and phosphothreonine, has made it possible to describe these novel phosphorylation sites in several proteins $[7,8]$.

Even though the analysis of fragmented peptides using MS tools is an alternative method, due to their negative charge and low abundance, phosphorylated peptides display poor ionization and are subjected to signal suppression, when compared to the regular, non-modified peptides $[7,9]$. Therefore, it is necessary to enrich for the phosphorylated peptides population present in the sample and to eliminate interfering ions. This may be accomplished by using a metal affinity chromatography, such as IMAC or $\mathrm{TiO}_{2}$, thus improving the detection levels of modified peptides $[8,10,11]$. This technique, coupled with stable isotope labeling of peptides for quantitative proteomics, may provide information on the proteins which are differentially phosphorylated during BMP2-induced osteodifferentiation. An unexpensive and practical method for quantitative proteomics is the use of stable-isotope dimethyl labeling [12]. Primary amine of tryptic peptides and the lysine $\varepsilon$-amino group can react with formaldehyde in the presence of cyanoborohydride through reductive amination, giving rise to dimethylated amine as the product. Depending on which stable isotope is used $\left({ }^{13} \mathrm{C}\right.$ or $\left.{ }^{2} \mathrm{H}\right)$, different shifts in molecular mass may be achieved. Using both non-modified formaldehyde and cyanoborohydride, the mass shift is of $28 \mathrm{Da}$. Using both deuterated formaldehyde and cyanoborohydride, the mass shift is of $32 \mathrm{Da}$, and using ${ }^{13} \mathrm{C}$ plus deuterated formaldehyde and cyanoborohydride, the mass shift is of $36 \mathrm{Da}$. Each isotope differs from each other by $4 \mathrm{Da}$ per primary amine labeled, with the comparison between different samples being made by MS precursor ion identification on extracted chromatograms [13].

Here, we employed mass spectrometry coupled to $\mathrm{TiO}_{2}$ metal affinity chromatography techniques to uncover new players involved in mouse skin mesenchymal cells (msMSCs) osteogenic differentiation.

\section{Results}

Quantitative phosphoproteome and proteome of msMSC cells subjected to rhBMP2 osteoblastic differentiation

msMSC cells cultured in $100 \mathrm{~mm}$ dishes were treated with rhBMP2 for different periods of time, in order to assess protein phosphorylation changes during the first steps of osteoblastic differentiation. Previous experiments using the osteoblast differentiation medium (ascorbic acid, beta-glycerolphosphate and dexamethasone) showed intense calcification of our murine skin MSCs in 14 and 21 days (Forni et al., personal comunication). Homogeneity of the skin dermal MSCs was probed through a complete characterization of $\mathrm{CD}$ markers, namely: CD31, CD90, CD34, CD73 and CD29 (Forni et al., unpublished data), utilizing only cell populations displaying greater than $90 \%$ purity for the osteogenic differentiation assays.

Due to the use of three different isotopes to label the samples and five different timepoints, it was necessary to carry out two independent experiments, each of which containing a light, an intermediate and a heavy isotope (Figures 1 and 2). We also evaluated protein level changes, through analysis of the total protein fraction $\left(\mathrm{TiO}_{2}\right.$ flow-through and washed peptides) in order to compare total protein levels alterations. Since the $\mathrm{TiO}_{2}$ Flowthrough and Wash fractions represent more than $70 \%$ of the sample [14] and are highly complex, another fractionation step was performed. HILIC separation was used to reduce sample complexity, according to protein hydrophilicity. 


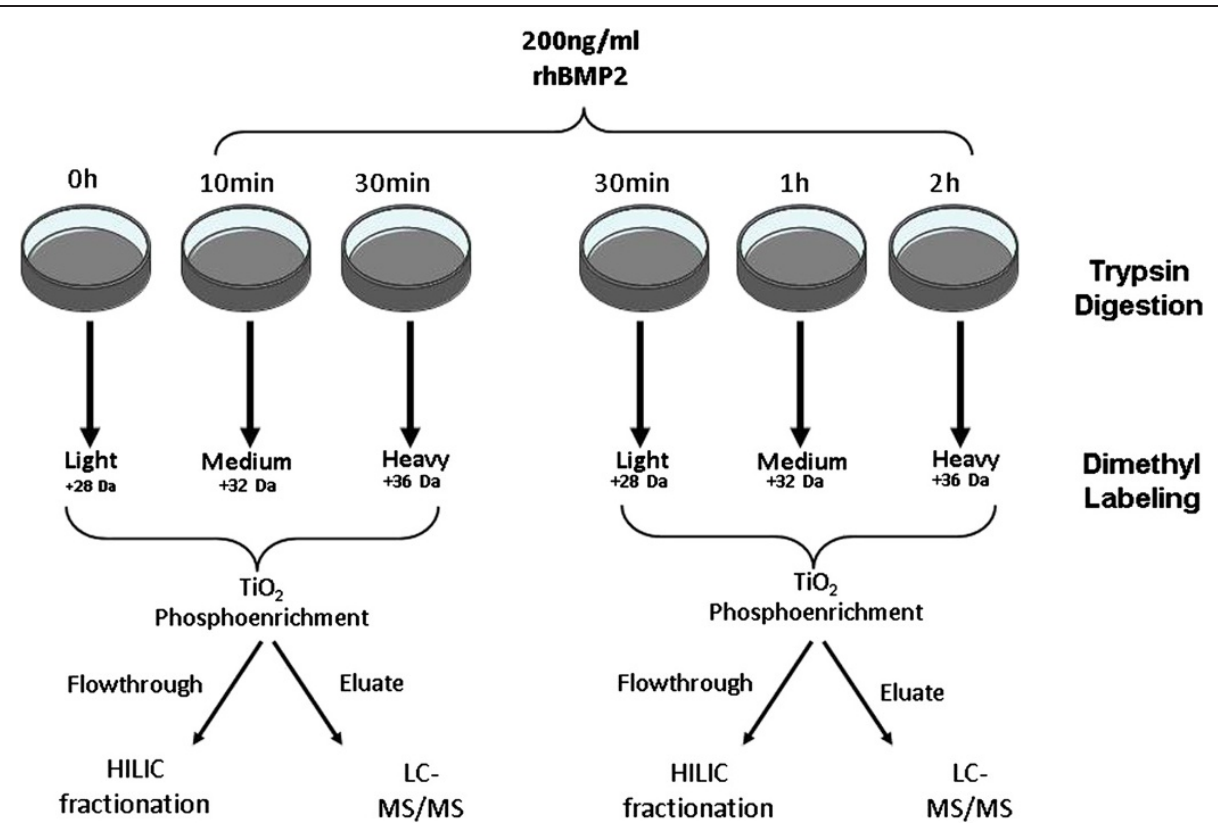

Figure 1 Induction of cells and mass spectrometry experiment outline.

\section{Data analysis}

The "raw" data acquired from Thermo LTQ-XL Orbitrap" was converted to ".mgf" files and an in-house MASCOT server was used to search for peptides containing dimethyl and carbamylation as a fixed modification and for phosphorylation in serine, tyrosine and threonine. The Thermo Proteome Discoverer software, version 1.1 was used to quantify all peptides based on the total area of Extracted Chromatogram (XIC), and the absolute values were normalized using a LOWESS (locally weighted scatterplot smoothing) algorithm (Figure 3). These data were input into the StatQuant software to evaluate the overall protein ratio by calculating the mean peptide ratio for all peptides corresponding to a given protein. The list for all peptides and phosphopeptides quantified can be accessed in the Additional file 1, and a summary of upregulated and downregulated phosphoproteins in each experiment, sorted by period of time indutction with rhBMP2 is shown in Additional file 2.

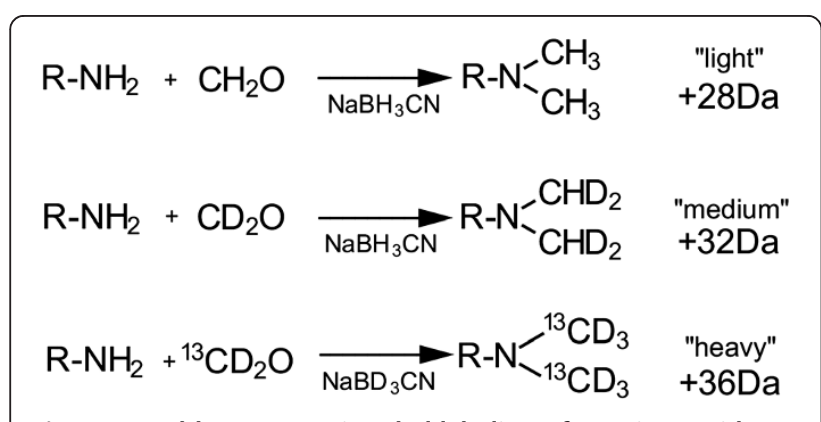

Figure 2 Stable Isotope Dimethyl labeling of tryptic peptides.

\section{Phosphosite localization}

To assign phosphorylation sites, normalized Mascot delta score (nMD-score) was used [15]. Mascot delta score is the difference between the top two scores for the peptides identified by a given spectrum. Dividing this value by the score of the top score (rank 1) peptide, normalized delta score is obtained. In order to have 1\% FLR (False Localization Rate) for correct phosphosite assignment with $99 \%$ certainty, peptides with nMD-score below 0.36 were discarded (corresponding to an MD-score of 10). A total of 950 unique phosphosites with $99 \%$ certainty that the sites were assigned correctly (1\% FLR) were identified. These sites were found on 235 different proteins and their distributions were $87.5 \%, 11.5 \%$ and $0.8 \%$ for $\mathrm{pS}$, pT and pY, respectively, which is comparable to previous works for mammalian cell types. All validated phosphosites with their MD-scores are listed in Additional file 1.

\section{Phosphorylation motif database search}

The analysis carried out to determine which kinase could possibly be involved in phosphsorylation of a given phosphorylated residue from phosphoproteome data was performed using the NetworKIN site (http://networkin. info/version_2_0/search.php). Figure 4 shows a summary of the complete dataset (Additional file 3) represented by a graph containing kinase motifs occurrencies.

\section{Network analysis using the ingenuity pathway analysis} software

In order to evaluate possible intracellular interactors with the phosphopeptides found, a network analysis was 


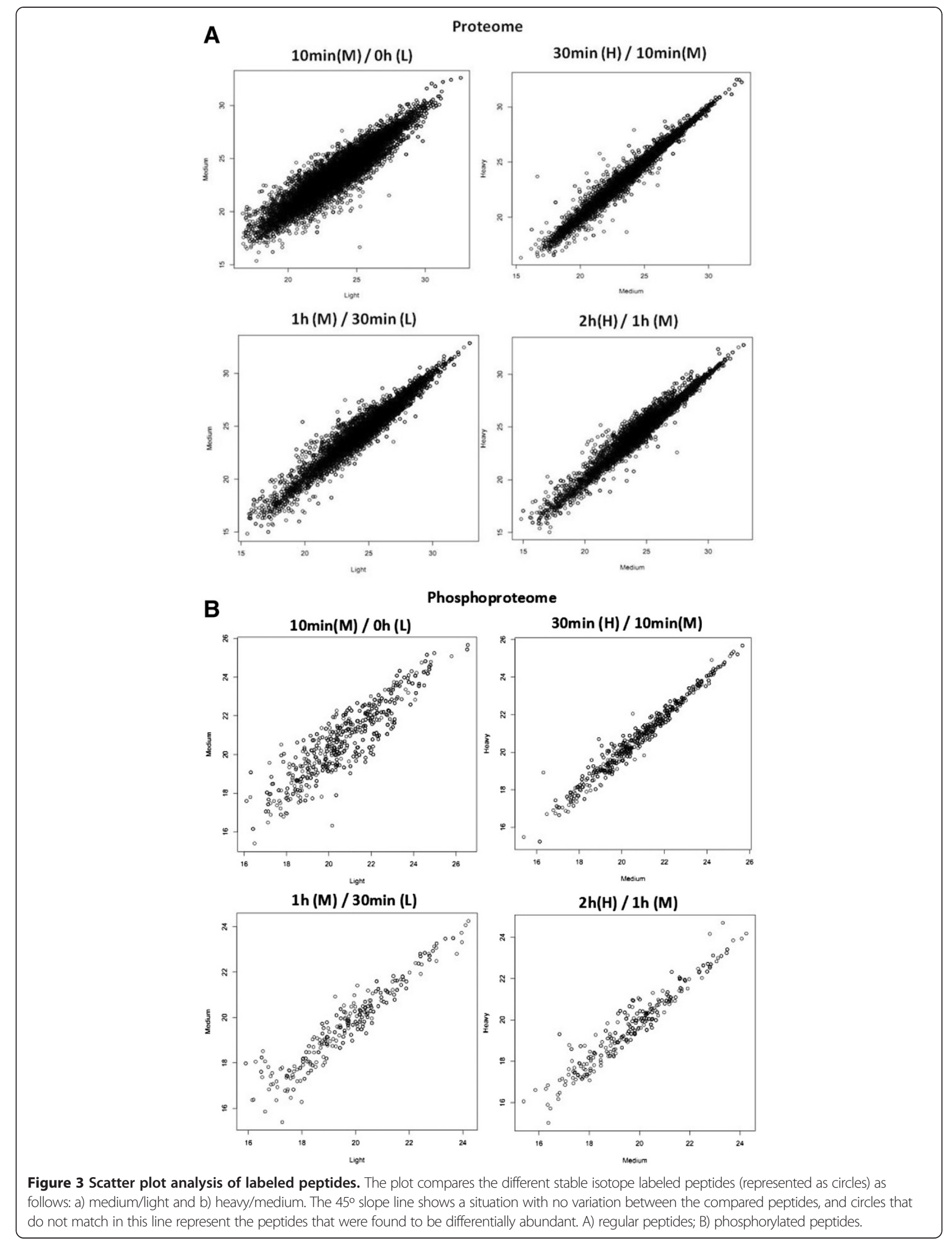

Proteome 


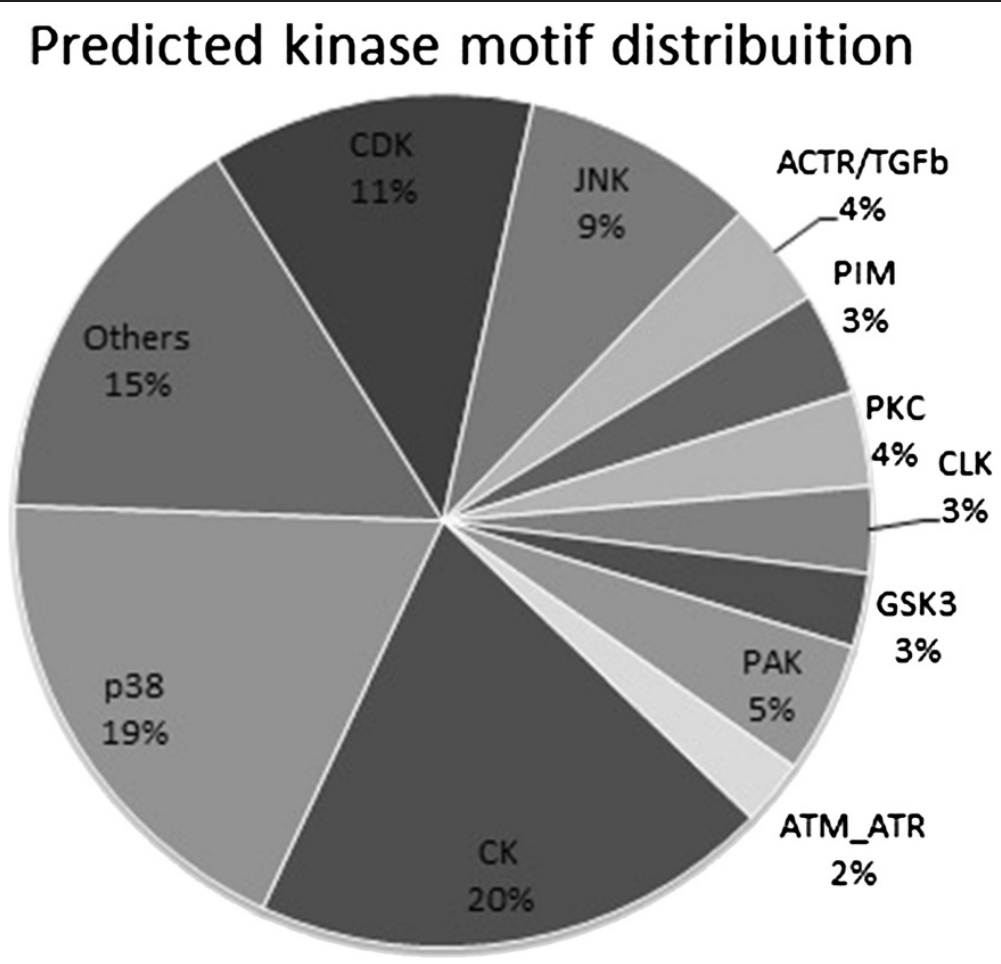

Figure 4 Predicted kinase motifs of substrates found in mass spectrometry experiments.

performed. The Ingenuity Pathway Analysis software (http://www.ingenuity.com/) was used to map relationships among proteins, distributed into different cellular compartments. From the total list of proteins found to interact with phosphoproteins (Table 1 and Additional files 4 and 5), hits containing a transcription factor function were selected for further analysis of DNA-binding motifs in osteoblast differentiation-related genes. Nonphosphorylated population of peptides were classified according to biological process using the Gene Ontology Blast2Go software (http://www.blast2go.com) in order to map and annotate gene ontologies (Table 2).

\section{Analysis of the promoter region of osteoblast-related genes for the presence of responsive elements for the BMP2-regulated transcription factors}

After obtaining the list of transcription factors for the Ingenuity ${ }^{\circ}$ network analysis, a curated database for transcription target genes, TRED was used to find target genes and text mining was performed to find which target genes are related with osteoblastic differentiation. We used the JASPAR database [16] which contains a curated, non-redundant set of profiles, derived from published collections of experimentally defined transcription factor binding sites for eukaryotes and sorted out the transcription factor which have well defined binding motifs (Figure 5) [17-19]. These motifs were used as a template for a search in the promoter region of the pre- selected genes, using the ENSEMBL cisRED database [20] and those which displayed at least one match or multiple matches for the sequences were selected for the qRT-PCR analysis (Additional file 6). The consensus sequences of sp1, c-Myc and NFkB were selected among others because they were present in the promoter region in more them $80 \%$ of the selected genes for qPCR validation.

\section{Analysis of differentially expressed genes involved in osteoblastogenesis activated by BMP2-induced transcription factors}

We used analysis of regulatory networks in order to investigate which transcription factors were activated, and which of them are related with activation of osteoblastrelated genes (Table 3). Thirteen genes were selected to evaluate their role in osteoblastic differentiation of msMSC cells, and to confirm the in silico analysis. From the initial list of genes investigated, ten (TGF-beta receptor, TGFbeta induced protein, Collagens 1and 4a1, Sox9, Smad2, Twist and the osteoblast-specific genes RUNX2, OSX and DLX5) were found to be upregulated at different timepoints (Figure 6). The TGFB cytokine ant its receptor, TGFBR1, displayed the regulated motifs in their promoter regions. The mRNA relative levels of these two genes were evaluated after $10 \mathrm{~min}, 30 \mathrm{~min}, 1 \mathrm{~h}$ and $2 \mathrm{~h}$ of exposure to rhBMP2. The relative levels of TGFB1 were upregulated more than two times after 30 min of rhBMP2 induction (Figure 6A, 3.2 fold, $\mathrm{p}<0.001$ ), but after reaching this peak, 


\begin{tabular}{|c|c|}
\hline BARD1 & BRCA1 associated RING domain 1 \\
\hline BMI1 & BMI1 polycomb ring finger oncogene \\
\hline CBX3 & Chromobox homolog 3 \\
\hline CTNNB1 & Catenin (cadherin-associated protein), beta 1, $88 \mathrm{kDa}$ \\
\hline $\mathrm{HIC1}$ & Hypermethylated in cancer 1 \\
\hline HMGA1 & High mobility group AT-hook 1 \\
\hline HNF4A & Hepatocyte nuclear factor 4, alpha \\
\hline ID3 & $\begin{array}{l}\text { Inhibitor of DNA binding 3, dominant negative helix-loop- } \\
\text { helix protein }\end{array}$ \\
\hline KDM5B & Lysine (K)-specific demethylase 5B \\
\hline MAZ & $\begin{array}{l}\text { MYC-associated zinc finger protein (purine-binding } \\
\text { transcription factor) }\end{array}$ \\
\hline MTA1 & Metastasis associated 1 \\
\hline MYC & v-myc myelocytomatosis viral oncogene homolog (avian) \\
\hline NFATC1 & $\begin{array}{l}\text { Nuclear factor of activated T-cells, cytoplasmic, calcineurin- } \\
\text { dependent } 1\end{array}$ \\
\hline NFKB1 & $\begin{array}{l}\text { Nuclear factor of kappa light polypeptide gene enhancer } \\
\text { in B-cells } 1\end{array}$ \\
\hline PPP1R13L & Protein phosphatase 1, regulatory (inhibitor) subunit 13 like \\
\hline $\mathrm{SIAH} 2$ & Seven in absentia homolog 2 (Drosophila) \\
\hline SMAD3 & SMAD family member 3 \\
\hline SOX4 & SRY (sex determining region Y)-box 4 \\
\hline SP1 & Sp1 transcription factor \\
\hline SREBF1 & Sterol regulatory element binding transcription factor 1 \\
\hline TFDP1 & Transcription factor Dp-1 \\
\hline TGFB111 & Transforming growth factor beta 1 induced transcript 1 \\
\hline TLE1 & $\begin{array}{l}\text { Transducin-like enhancer of split } 1 \text { (E(sp1) homolog, } \\
\text { Drosophila) }\end{array}$ \\
\hline YAP1 & Yes-associated protein 1 \\
\hline CBX4 & Chromobox homolog 4 \\
\hline E2F4 & E2F transcription factor 4, p107/p130-binding \\
\hline
\end{tabular}

Predicted network of interaction for phosphoproteins found using Ingenuity Pathway Analysis. The list of phosphoproteins found were subjected to Ingenuity Pathway Analysis (IPA) to investigate problable protein interactions for each cellular compartment. Proteins described to be transcription factors were selected to investigate the activation of osteblast related genes by quantitative real-time PCR.

the relative levels decreased to basal levels after $2 \mathrm{~h}$. This pattern was followed by a subsequent increase in the TGFBR1 mRNA relative levels of up to 3.6 fold at $1 \mathrm{~h}$ and more than 4.9 fold at $2 \mathrm{~h}$ (Figure 6B, $\mathrm{p}<0.001$ ). Since the synthesis of extracellular matrix compounds, such as collagens, is known to be regulated during osteo differentiation, we selected two members of the collagen family that displayed the selected motifs, namely: collagen 1 and 4a. Both ECM components were upregulated, with collagen 1 displaying a punctual increase at $1 \mathrm{~h}$ after stimulus (Figure 6C, 8.6 fold, $\mathrm{p}<0.001$ ) and collagen $4 \mathrm{a}$ followed a progressively rising pattern (Figure 6D, 5.96 fold at $1 \mathrm{~h}$ and 10.8 at $2 \mathrm{~h}, \mathrm{p}<0.05$ and $\mathrm{p}<0.001$, respectively). Related to collagens and TGFB, the osteogenesis related gene Twist presents a downregulation pattern ( 0.39 fold after $10 \mathrm{~min}$ ) from the basal levels during the beginning of the differentiation and after that a slight increase (1.6 fold) at $1 \mathrm{~h}$, a decrease to 1.2 fold at $2 \mathrm{~h}$ (Figure 6E, p<0.05). Expression of SMAD2 was accessed, in order to stabilish a possible crosstalk between TGF-beta/Activin signaling during BMP2-driven osteogenesis. The mRNA relative levels of SMAD2 were accessed, presenting a slight increase of 3.4 fold at $10 \mathrm{~min}$ and a major increase of more than 7.5 fold at $2 \mathrm{~h}$ (Figure 6F, $\mathrm{p}<0.001$ ).

We also evaluated a set of four transcription factors which, in addition to presenting the regulated motifs in their promoter regions, were key elements during the osteoprogenitors differentiation. The relative mRNA levels of RUNX2 were the first to be upregulated, increasing almost 400 fold after $30 \mathrm{~min}$, with a drastic descent to levels similar to basal levels after $1 \mathrm{~h}$ (Figure 7A, $\mathrm{p}<0.001)$. Another important transcription factor, DLX-5, displayed a progressive increase at $10 \mathrm{~min}(14.4$ fold, $\mathrm{p}<0.05)$ and $30 \mathrm{~min}(72.9$ fold, $\mathrm{p}<0.001)$ reaching a peak at $1 \mathrm{~h}$ (135.2 fold, $\mathrm{p}<0.001)$, followed by a sharp decrease to basal levels at $2 \mathrm{~h}$ (Figure 7B). The transcription factor Osterix displayed a stepwise increase, beginning at $10 \mathrm{~min}$, and reaching up to 10 fold after $2 \mathrm{~h}$ of stimulation (Figure 7C, p<0.001). Similarly, the SOX9 mRNA level was upregulated at $30 \mathrm{~min}$ (6.4 fold, $\mathrm{p}<0.05)$ and $1 \mathrm{~h}$ (15.2 fold, $\mathrm{p}<0.001)$ (Figure 7D).

\section{Discussion}

In the present study, we used murine skin mesenchymal cells (msMSC) and stable dimethyl isotope labeling to quantify abundant proteins and phosphoproteins using $\mathrm{TiO}_{2}$ metal affinity chromatography, coupled with mass spectrometry, at five different periods of rhBMP2 induction, namely: 0, 10, 30, 60 and $120 \mathrm{~min}$. From $150 \mu \mathrm{g}$ of the combined samples, it was possible to identify and quantify 235 distinct phophoproteins and 2,029 distinct proteins, in all replicates. Based on the data acquired, and, also, on references from the literature, we proposed a model for BMP2-mediated osteodifferentiation differentiation of these msMSCs cells. Previous experiments carried out with these msMSCs, subjected to the osteoblast differentiation medium (ascorbic acid, beta-glycerolphosphate and dexamethasone) showed intense calcification at 14 and 21 days of treatment, with greater than $80 \%$ of the cells being Alizarin Red-positive" (Forni et al., unpublished data). This experiment could not be carried out solely with BMPs-supplemented culture medium, due to its lack of mineral components (e.g. beta-glycerolphosphate), which is necessary for mineralization.

The data found showed to be compatible with bone development, since BMPs act at the very early stages of 
Table 2 Protein annotation for biological processes of upregulated proteins

\begin{tabular}{|c|c|c|c|c|c|c|c|c|c|c|c|}
\hline \multicolumn{3}{|c|}{$10 \mathrm{~min} / 0 \mathrm{~h}$} & \multicolumn{3}{|l|}{$30 \mathrm{~min} / 10 \mathrm{~min}$} & \multicolumn{3}{|l|}{$1 \mathrm{~h} / 30 \mathrm{~min}$} & \multicolumn{3}{|l|}{$2 \mathrm{~h} / 1 \mathrm{~h}$} \\
\hline GO term & \#Seq & Score & GO term & \#Seq & Score & GO term & \#Seq & Score & GO term & \#Seq & Score \\
\hline Signaling & 14 & 4,21 & Signaling & 31 & 8,92 & Signaling & 40 & 13,3 & Developmental process & 47 & 15 \\
\hline $\begin{array}{l}\text { Cellular response to } \\
\text { stimulus }\end{array}$ & 19 & 5,67 & $\begin{array}{l}\text { Anatomical structure } \\
\text { development }\end{array}$ & 22 & 9,48 & $\begin{array}{l}\text { Multicellular organismal } \\
\text { development }\end{array}$ & 48 & 12,78 & Signaling & 17 & 4,13 \\
\hline $\begin{array}{l}\text { Anatomical } \\
\text { structure } \\
\text { morphogenesis }\end{array}$ & 13 & 4,21 & $\begin{array}{l}\text { Multicellular organismal } \\
\text { development }\end{array}$ & 8 & 2,39 & $\begin{array}{l}\text { Anatomical structure } \\
\text { development }\end{array}$ & 46 & 13,06 & Anatomical structure development & 41 & 12,3 \\
\hline Cell differentiation & 18 & 5,95 & Cell differentiation & 6 & 2,48 & Cell-cell signaling & 9 & 2,96 & Multicellular organismal development & 43 & 8,57 \\
\hline $\begin{array}{l}\text { Regulation of } \\
\text { signaling }\end{array}$ & 6 & 1,08 & $\begin{array}{l}\text { Cell surface receptor linked } \\
\text { signaling pathway }\end{array}$ & 3 & 2,6 & Cell activation & 7 & 3,18 & Cell differentiation & 20 & 9,36 \\
\hline $\begin{array}{l}\text { Cell morphogenesis } \\
\text { involved in } \\
\text { differentiation }\end{array}$ & 7 & 2,06 & $\begin{array}{l}\text { Cell morphogenesis involved } \\
\text { in differentiation }\end{array}$ & 30 & 5,77 & System development & 40 & 10,12 & Cell surface receptor linked signaling pathway & 9 & 3,63 \\
\hline Organ development & 21 & 8 & $\begin{array}{l}\text { G-protein coupled receptor } \\
\text { protein signaling pathway }\end{array}$ & 4 & 3,2 & Cell differentiation & 33 & 15,09 & Embryo development & 7 & 3,14 \\
\hline $\begin{array}{l}\text { Regulation of cell } \\
\text { differentiation }\end{array}$ & 6 & 1,12 & Signal transduction & 8 & 2,14 & Cytoskeleton organization & 26 & 9,55 & System development & 36 & 8,95 \\
\hline \multirow[t]{11}{*}{ Signal transduction } & 11 & 5,73 & Epithelial cell differentiation & 13 & 6,01 & Regulation of signaling & 20 & 6,75 & Cell development & 15 & 5,97 \\
\hline & & & Phosphorylation & 14 & 4,67 & $\begin{array}{l}\text { Cell surface receptor linked } \\
\text { signaling pathway }\end{array}$ & 18 & 7,95 & Cell morphogenesis involved in differentiation & 9 & 2,47 \\
\hline & & & $\begin{array}{l}\text { Transmembrane receptor } \\
\text { protein tyrosine kinase } \\
\text { signaling pathway }\end{array}$ & 4 & 2,56 & Signal transduction & 37 & 18,99 & Organ development & 26 & 10,7 \\
\hline & & & & & & Organ development & 26 & 11,08 & Regulation of signal transduction & 6 & 2,1 \\
\hline & & & & & & $\begin{array}{c}\text { Cell morphogenesis involved in } \\
\text { differentiation }\end{array}$ & 13 & 3,15 & Signal transduction & 17 & 6,54 \\
\hline & & & & & & $\begin{array}{l}\text { Enzyme linked receptor protein } \\
\text { signaling pathway }\end{array}$ & 9 & 3,8 & Epithelial cell differentiation & 2 & 2 \\
\hline & & & & & & $\begin{array}{l}\text { Intracellular protein kinase } \\
\text { cascade }\end{array}$ & 7 & 3,34 & Regulation of gene expression & 14 & 4,89 \\
\hline & & & & & & $\begin{array}{l}\text { G-protein coupled receptor } \\
\text { protein signaling pathway }\end{array}$ & 6 & 4,77 & $\begin{array}{l}\text { Transmembrane receptor protein tyrosine kinase } \\
\text { signaling pathway }\end{array}$ & 5 & 2,92 \\
\hline & & & & & & $\begin{array}{l}\text { Small GTPase mediated signal } \\
\text { transduction }\end{array}$ & 5 & 2,01 & $\begin{array}{l}\text { DNA damage response, signal transduction by } \\
\text { p53 class mediator resulting in cell cycle arrest }\end{array}$ & 3 & 3 \\
\hline & & & & & & $\begin{array}{l}\text { Second-messenger-mediated } \\
\text { signaling }\end{array}$ & 3 & 1,22 & $\begin{array}{l}\text { Negative regulation of ubiquitin-protein ligase } \\
\text { activity involved in mitotic cell cycle }\end{array}$ & 4 & 4 \\
\hline & & & & & & Wnt receptor signaling pathway & 3 & 1,08 & $\begin{array}{l}\text { Positive regulation of ubiquitin-protein ligase } \\
\text { activity involved in mitotic cell cycle }\end{array}$ & 4 & 4 \\
\hline
\end{tabular}


Table 2 Protein annotation for biological processes of upregulated proteins (Continued)

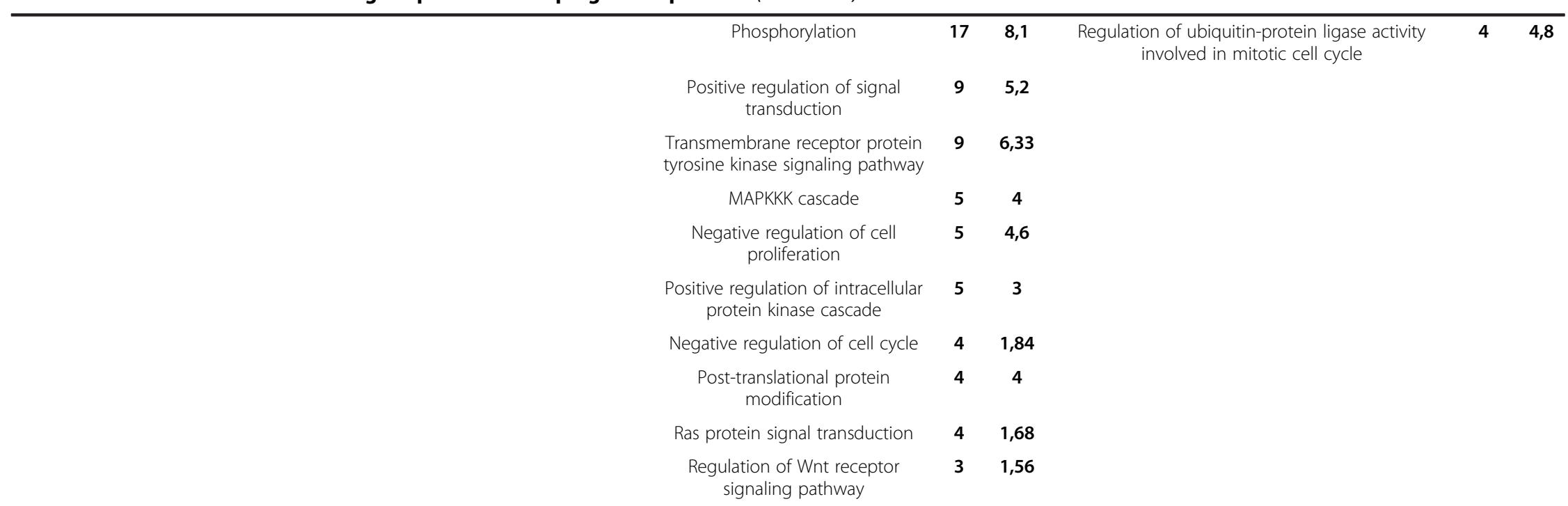

Consistently upregulated proteins were input in Blast2go software for mapping and annotation of gene ontologies. Biological processes over-represented were selected and classified according to level. Top: low levels; bottom. 

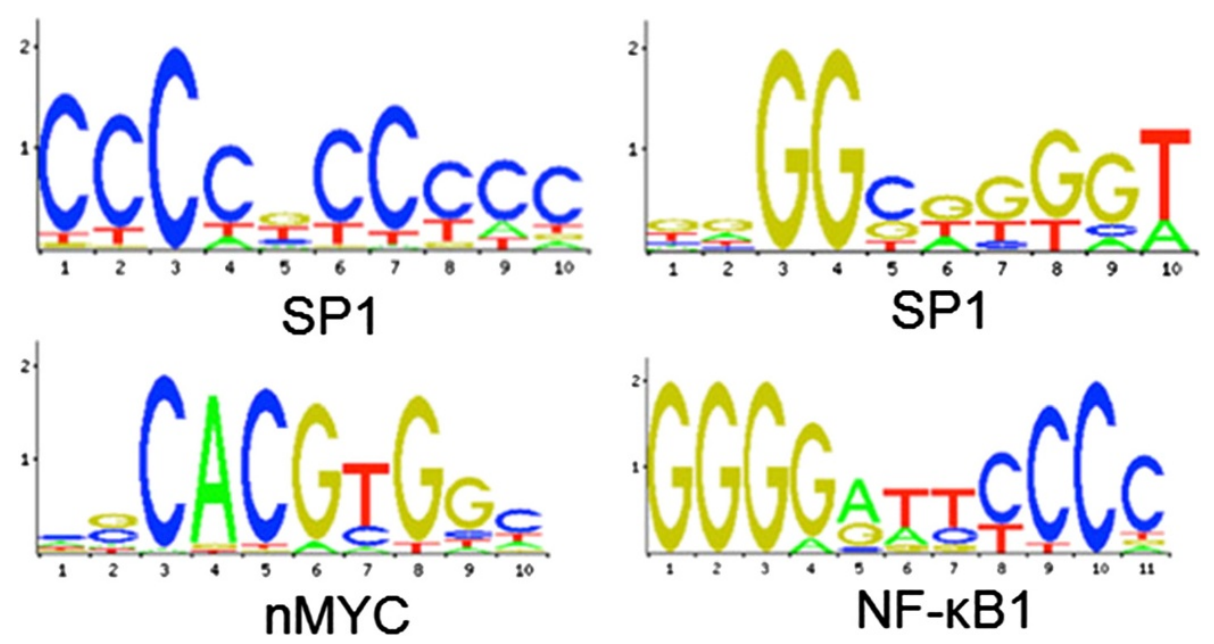

Figure 5 Transcription factor motifs found for selected osteodifferentiation genes.

Table 3 List of Primers used in qRT-PCR

\begin{tabular}{|c|c|}
\hline Gene & 5'- 3' nucleotide sequence \\
\hline mBMP-2 F & TCTTCCGGGAACAGATACAGG \\
\hline mBMP-2 R & TGGTGTCCAATAGTCTGGTCA \\
\hline mOsterix $\mathrm{F}$ & ATGGCGTCCTCTCTGCTTG \\
\hline mOsterix R & TGAAAGGTCAGCGTATGGCTT \\
\hline mRunX-2 F & GACTGTGGTTACCGTCATGGC \\
\hline mRunX-2 R & ACTTGGTTITCATAACAGCGGA \\
\hline mDlx5 F & CACCACCCGTCTCAGGAATC \\
\hline mDlx5 R & GCTITGCCATAAGAAGCAGAGG \\
\hline mTGFb1 F & CTCCCGTGGCTTCTAGTGC \\
\hline mTGFb1 R & GCCTTAGTTTGGACAGGATCTG \\
\hline mSMAD-2 F & ATGTCGTCCATCTTGCCATTC \\
\hline mSMAD-2 R & AACCGTCCTGTITTCTITAGCTT \\
\hline mTGFbR2 F & CCGCTGCATATCGTCCTGTG \\
\hline mTGFbR2 R & AGTGGATGGATGGTCCTATTACA \\
\hline mTwist1 F & GGACAAGCTGAGCAAGATTCA \\
\hline mTwist1 R & CGGAGAAGGCGTAGCTGAG \\
\hline mSox9 F & GAGCCGGATCTGAAGAGGGA \\
\hline mSox9 R & GCTTGACGTGTGGCTTGTTC \\
\hline $\mathrm{mCol4a} 1 \mathrm{~F}$ & CTGGCACAAAAGGGACGAG \\
\hline mCol4a1 R & ACGTGGCCGAGAATTTCACC \\
\hline $\mathrm{mCol}-1 \mathrm{~F}$ & GCTCCTCTTAGGGGCCACT \\
\hline mCol-1 R & ATTGGGGACCCTTAGGCCAT \\
\hline $\mathrm{mCol}-2 \mathrm{~F}$ & CAGGATGCCCGAAAATTAGGG \\
\hline $\mathrm{mCol}-2 \mathrm{R}$ & ACCACGATCACCTCTGGGT \\
\hline
\end{tabular}

List of primers used to amplify the CDNA in order to investigate changes in mRNA upon BMP2 treatment in qRT-PCR. F: forward; R: reverse. cells differentiation to the osteoblastic lineage, but, later on in the process, these cells incorporate mineral precursors and originate the calcified bone tissue. The kinases which showed the highest number of phosphorylation motifs in phosphodata were represented, as well as gene activation for each time period studied (Figure 8).

We used triplex stable isotope dimethyl labeling to compare five different time periods of rhBMP2-induced osteoblastic differentiation of skin mesenchymal cells, combined into two different experimental groups (an "early period" group, which comprised the $0 \mathrm{~h}, 10 \mathrm{~min}$ and $30 \mathrm{~min}$ samples and a second, "late period" group, comprised of the $30 \mathrm{~min}, 1 \mathrm{~h}$ and $2 \mathrm{~h}$ samples). This was necessary in order to correctly compare the phosphoprotein ratios with their respective protein levels, since we do not expect a wide protein level variation during the period studied and, also, to avoid aberrations in phosphoprotein variation. Similarly, Song and colleagues [21] used similar approach through a pseudo-triplex dimethyl labeling in liver tissue samples and hepatocellular carcinoma.

Each pooled sample was split according to the affinity of peptides for the $\mathrm{TiO}_{2}$ column. The $\mathrm{TiO}_{2}$-Flowthrough fraction was subjected to HILIC and fractionated. Since this step decreased the sample complexity, it enhanced the number of peptides which could be identified and quantified, when compared to the entire pool, which was directly injected into the LC/MS (data not shown). Since we started from a relatively low amount of sample (50 $\mu \mathrm{g}$ of protein extract for each timepoint and $150 \mu \mathrm{g}$ for a triplex experiment), no improvement in the number of detected peptides was obtained using HILIC in phospho-enriched samples. Analysis of the data also showed that there is a tendency for many phosphopeptides to be upregulated between $30 \mathrm{~min}$ and $1 \mathrm{~h}$ of rhBMP2 treatment, correlating with the period of activation for the Dlx5 transcription factors which trigger the expression of 

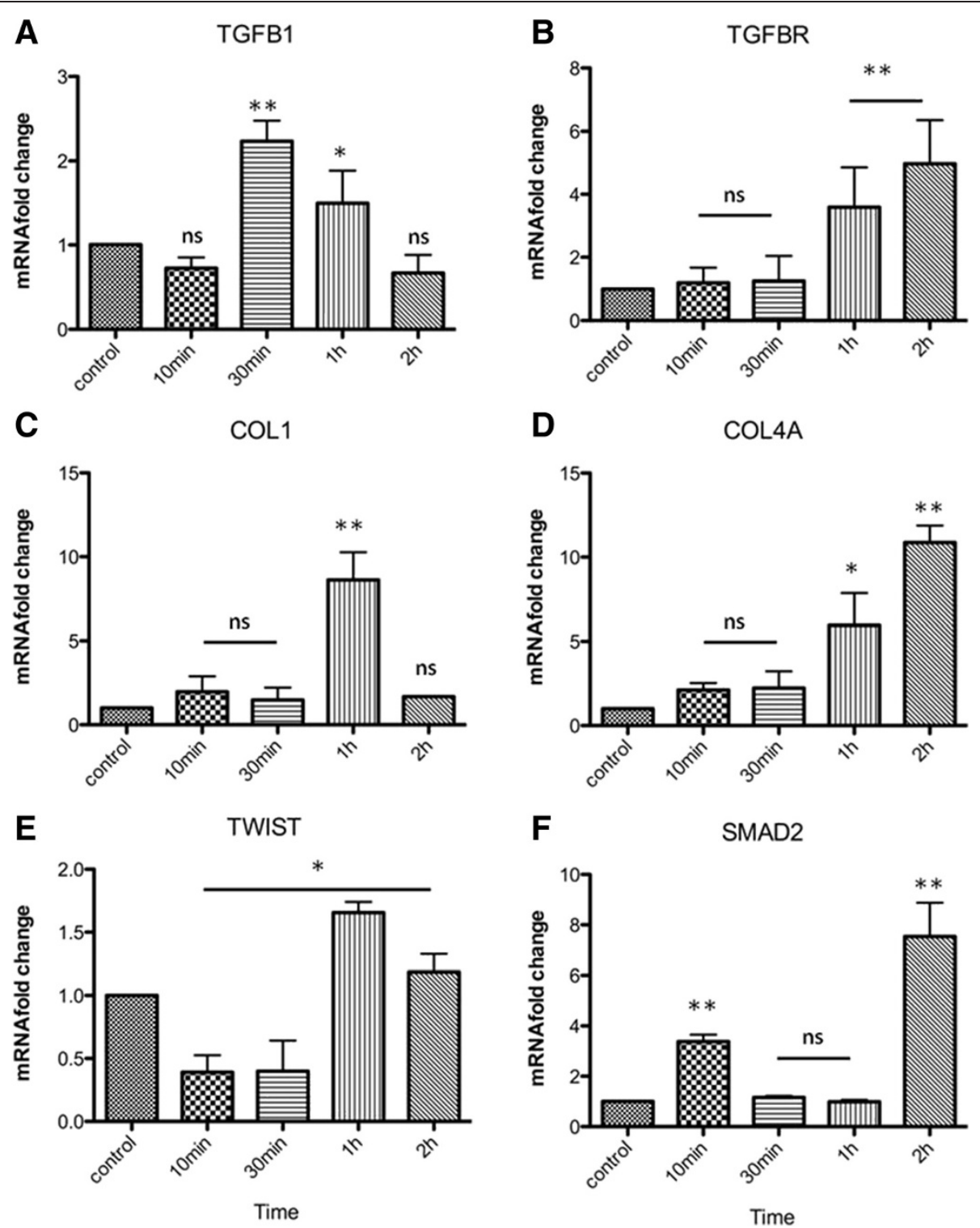

Figure 6 mRNA fold change measured by qRT-PCR for osteoblast related genes. Quantitative Real Time PCR of osteoblast related genes from rhBMP2 induced SMSC at indicated timepoints were normalized and compared according to housekeeping genes as control: mHPRT hypoxanthine phosphoribosyltransferase 1, mGAPDH - glyceraldehyde-3-phosphate synthase and mHMBS - mouse hydroxymethylbilane synthase. A) TGFB1 relative levels were upregulated 3.2 fold after 30 min of rhBMP2 induction $(p<0.001)$ followed by a decrease to basal levels after $2 \mathrm{~h}$. B) TGFBR1 mRNA increase levels of up to 3.6 fold at $1 \mathrm{~h}$ and more than 4.9 fold at $2 \mathrm{~h}$ (Figure 6B, p<0.001). C) COL1 displays a punctual increase at $1 \mathrm{~h}$ after stimulus (8.6 fold, $\mathrm{p}<0.001$ ). D) COL4A showed a progressively rising pattern at timepoints studied (5.96 fold at $1 \mathrm{~h}$ and 10.8 at $2 \mathrm{~h}$, $p<0.05$ and $p<0.001$, respectively). E) TWIST is downregulated ( 0.39 fold after $10 \mathrm{~min}$ ) but after $1 \mathrm{~h}$ shows a slight increase (1.6 fold) at $1 \mathrm{~h}$. F) SMAD2 presented a slight increase of 3.4 fold at $10 \mathrm{~min}$ and $2 \mathrm{~h}(\mathrm{p}<0.001)$. Data represent three independent experiments and standard deviation bar is shown for all experimental timepoints studied. Asterisks represents levels of significance for statistical analysis (Two-Way ANOVA, Bonferroni test) between control and treatment groups ( ${ }^{*} p<0,05$ and $\left.{ }^{* *} p<0,01\right)$. ns: non statistically significant.

RUNX2 and OSX, both of which are upregulated upon rhBMP2 administration [22,23].

In order to compare measurements across LC-MS/MS experiments and to correct for non-biological variation (such as the bias generated in the sample quantification), data normalization is a crucial step prior to any further analysis. The standard normalization assumed in LC/MS experiments is based on dividing all peptide ratio values by $\log 2$. However, notice that this procedure only divides the peptide abundance by a common factor, re-scaling the relative abundance of the peptide. In other words, this "within sample" normalization does not remove the bias in the quantities across experiments. In order to remove the systematic errors introduced in different experiments, 


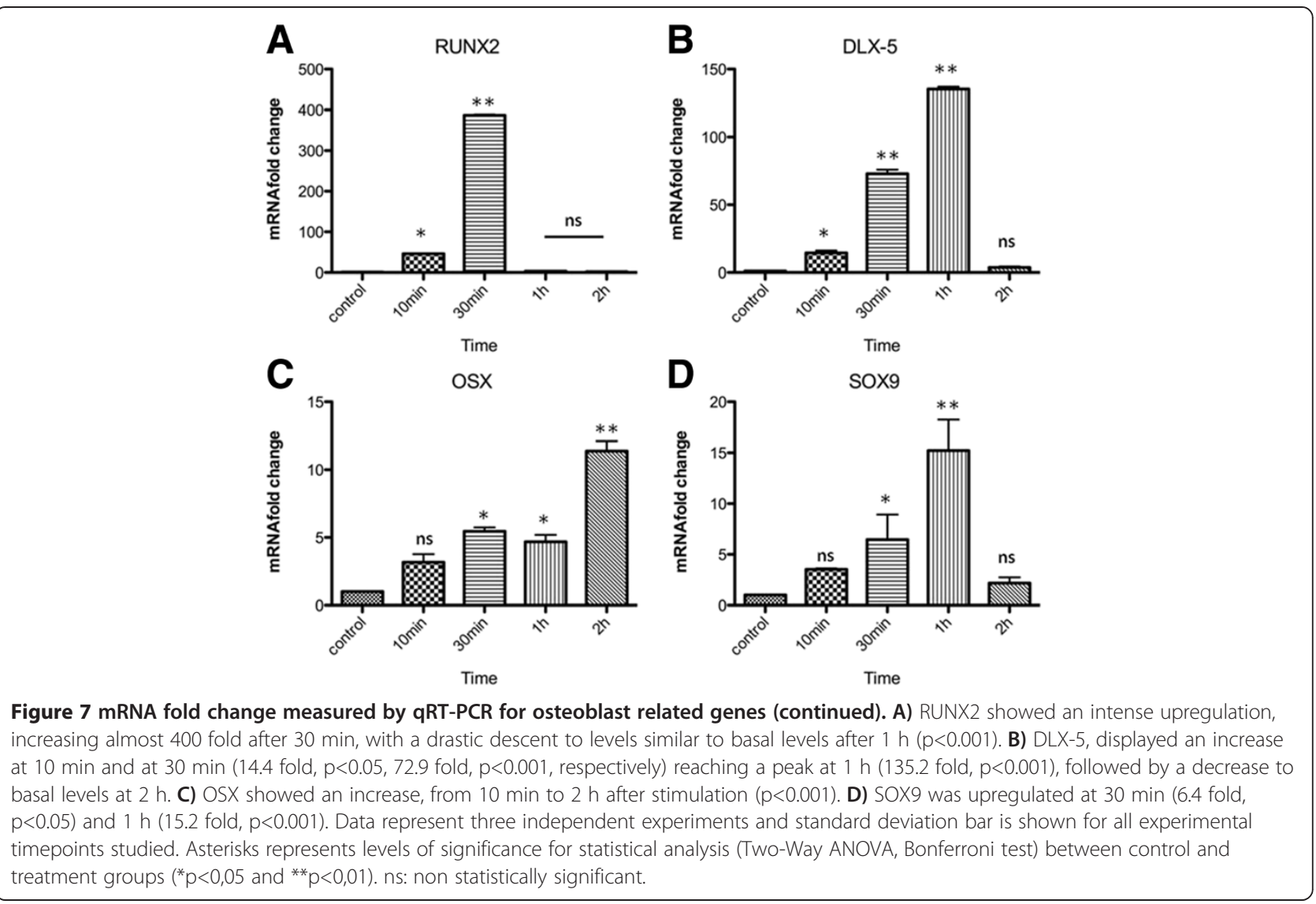

we applied the LOWESS regression, a technique commonly applied to microarray data analysis [24]. One premise to apply LOWESS normalization is that the differences among the overall intensity of different experiments would be the consequence of non-biological variation, i.e., most peptides will not show a significant change in the abundance between the two compared samples (peptides derived from closely related samples). Briefly, in a well performed experiment, the scatter-plot of peptides of one sample versus another would cluster the peptides along a straight line, and the slope would be equal to 1. Normalization of these data is equivalent to calculating the best-fit slope using regression techniques and adjusting the intensities so that the calculated slope is 1 . However, sometimes, the intensities may be nonlinear, therefore, local regression techniques, such as LOWESS regression, are more suitable. LOWESS regression [25] is estimated through a locally weighted polynomial regression for a subset of peptides in the neighborhood of each peptide. For more details, please refer to [26].

\section{BMP2 induces phosphorylation of substrates for different} kinases in msMSCs

Kinase prediction analysis using the NetworKIN database, from the phosphorylated peptides found, suggested that, three major kinases could be acting as effectors of phosphorylation upon BMP2 treatment, namely: Casein kinase II (CK2), p38 MAPK and JNK. These kinases are followed, to a lesser extent, by Activin receptors and the CDK family of kinases. These data are in agreement with the literature of the field, since Bragdon and colleagues $[27,28]$ showed the involvement of CK2 in BMP2induced cells. The release of CK2 from BMP receptor type I (BMPRI) is related with osteblastogenesis, since specific peptides which interfere with this interaction, destabilize the CK2-BMPRI complex and enhance osteoblastic differentiation. It is possible that the role of CK2 in osteogenesis is much more than its release from BMPRI, involving many of the substrates found in this work and even other ones which could contribute to the enrollment of these undifferentiated stem cells to osteoblastogenesis.

The involvement of p38 MAPK in BMP2-driven osteoblatogenesis is well-known. Several studies $[1,23]$ show activation of p38 within the first hour of BMP2 induction, and activation of Dlx 5 and Osx, essential genes involved in osteblastic differentiation [23], as well as alkaline phosphatase. We confirmed these data in our model using quantitative real-time PCR experiments, showing an increase in mRNA relative expression for Osx and Dlx5. It is interesting to note that p38 may be 


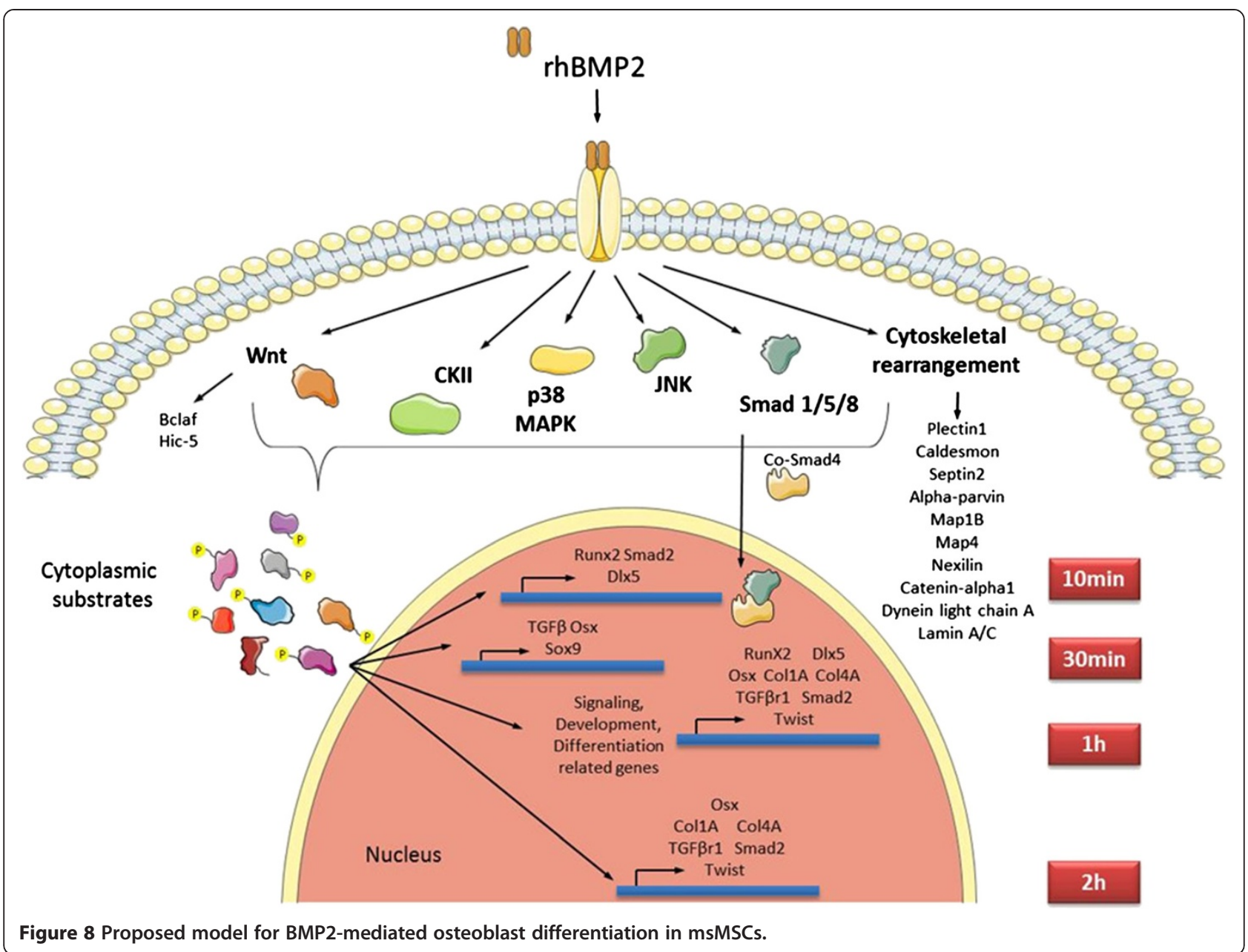

involved in phosphorylation of several phosphoproteins found in our study, since 120 sites were predicted to be phosphorylated by this kinase.

Upon BMP2 treatment, JNK may also be activated, as previous studies described [29-32]. We found that $9 \%$ of all sites could be phosphorylated by this kinase up to $2 \mathrm{~h}$ of BMP2 treatment. Interestingly, JNK is transiently activated in MC3T3-E1cells, in a short window (from $2 \mathrm{~h}$ to $4 \mathrm{~h}$ after BMP2 induction), stimulating the expression of osteocalcin. However, at late periods of BMP2 induction, JNK acts inhibiting the RUNX2 function by its phosphorylation at Ser 104 in C2C12 cells [30]. These results show the dual function of JNK in osteoblastogenesis, which is regulated in a time-dependent manner. At early periods of time, JNK may have a role inducing osteogenesis, by phosphorylating intracellular substrates and augmenting the cellular sensibility for BMP2 [31]. On the other hand, at late periods, JNK would participate by slowing down the intracellular signaling for osteodiffentiation.

Similar number of phosphorylated sites were found for the CDK group of kinases. These kinases are related with cell cycle progression, and their activation or inhibition is associated with proliferation and quiescence, respectively. At a first glance, the activity of CDK kinases could lead to an impairment of osteoblastic differentiation, due to stimulation of cell proliferation. The role of CDK in osteoblastic differentiation is not well understood yet, however, its inhibitor, the $\mathrm{p} 21$ protein, has been involved in osteoblastic differentiation since p21 null mice exhibit enhanced osteoblastic differentiation, and overexpression of $\mathrm{p} 21$ protein delays bone formation [33]. It is possible that p21 could act independently of $\mathrm{CDK}$, activating or repressing genes in the nucleus, with its role controlling osteoblastic differentiation being more complex than simply regulating the cell cycle. Further studies will be required to address this issue and how CDK/p21 regulation participates in osteoblastic differentiation.

\section{Biological processes overrepresented in BMP2-treated msMSCs}

The proteomic data obtained were analyzed using the Gene Ontology classification. We observed which gene ontologies could be representative of the upregulated genes. Surprisingly, we found a high number of ontologies 
containing the following terms: multicellular organismal and anatomical structure development (48 and 46 entries, score 12.78 , and 13.06 respectively), signal transduction (37 entries, score 18.99) signaling (40 entries, score 13.3), cell differentiation (33 entries, score 13.06), cell surface receptor linked signaling pathway (18 entries, score 7.95) and phosphorylation (17 entries, score 8.1) at the first hour of BMP2 treatment, in contrast with the first 10 and 30 min periods of induction, which showed a few gene ontologies with these terms assigned. This can be due to the fact that short periods of time are not sufficient to change the overall amount of protein in the cell [34], therefore, transcription and translation of new proteins must take place before we can observe changes in protein levels, which are sufficient to affect the gene ontologies classification observed. Nevertheless, comparing the second hour of BMP2 induction with the first one, less gene ontologies could be classified, leading to the conclusion that these proteins involved with signaling are regulated within the first hour BMP2 induction.

\section{BMP2-treated msMSCs phosphorylate intracellular messengers which, in turn, activate osteoblastic-related genes}

BMP2 induction was shown to modify the posttranslational modifications of intracelular proteins, at the timepoints studied. In order to investigate how these phosphorylated proteins activate transcription factors, and whether they are related with the activation of osteoblastic genes, a network analysis of proteins found in the phosphoproteome of BMP2-treated msMSCs was carried out. Through Ingenuity network analysis, we found different transcription factors related with the phospho data. However, not all of the transcription factors found were described to have any participation in osteoblast differentiation, or activation of osteoblastic related genes. Using a curated database for transcription target genes, TRED, a transcription factors binding motifs occurrence, JASPAR, and the literature on the field to search for osteoblastic target genes, one by one, we found three transcription factors from the Ingenuity output list, displaying important roles in osteoblastogenesis, namely: SP1, c-Myc e NF-kB.

TGF- $\beta$ /BMPs are widely recognized for their role in bone formation during mammalian development, exhibiting versatile regulatory functions in the body [35]. In accordance with this finding, we observed increased levels of the mRNA for both the TGFB cytokine and for its receptor TGFBR. Also, signaling transduction by TGF- $\beta /$ BMPs occurs specifically through both canonical Smad-dependent pathways (TGF- $\beta /$ BMP ligands, receptors and Smads) and a non-canonical Smad-independent signaling pathway (e.g. p38 mitogen-activated protein kinase pathway, MAPK). Following TGF- $\beta /$ BMP induction, both the Smad and p38 MAPK pathways converge at the RUNX2 gene to control mesenchymal precursor cell differentiation, which has also been found to have increased mRNA levels.

SOX9, a transcription factor of the sex-determining region Y (SRY)-related high mobility group box family of proteins, is crucial for skeletal development and marks all osteoblastic progenitors [36], being capable of inducing RUNX2 expression [37-39]. However, the role of SOX9 in osteoblastic differentiation is not completely understood. Conditional deletion of SOX9 in the limb bud mesenchyme led to the absence of chondrocytes and osteoblasts [40]. Contrastingly, when SOX9 was deleted in the neural crest cells that contribute to the craniofacial skeleton, the cells which normally form chondrocytes expressed osteoblasts markers [41], suggesting the existence of a the bipotential progenitor. However, SOX9 is not expressed by mature osteoblasts [36] and this is the probable cause of its downregulation after $2 \mathrm{~h}$ of the stimulus.

COL1 and COL4A display functions related with the building of the basal membrane for the newly-formed mature bone tissue. A recent report of comparative transcription of various fetal and adult mesenchymal stem cells sources through quantitative PCR profiling unveiled that collagens, such as collagen 1 and 4 , were upregulated during several types of osteogenic differentiation, such as the one reported in this manuscript with the levels of these two extracellular matrix components being increased [42]. Supporting these findings, it has been reported that site mutations in collagen 1 leads to high bone mass in osteogenesis imperfecta [43].

Since the bHLH transcription factor Twist inhibits osteoblast differentiation through binding to a DNAbinding domain in RUNX2 [44], the early downregulation of this gene to levels below the basal level at 10 and 30 min could be indicative that the differentiation process was mediated by RUNX2. Moreover, it has been shown that RUNX2, a Runt domain-containing transcription factor, is indispensable for osteoblastic differentiation during both endochondral and intramembranous ossification and the function of mature osteoblasts, including the synthesis of bone matrix. Homozygous deletion of Runx2 in mice resulted in a complete lack of osteoblasts [41]. Our results show a sustained increase in the mRNA levels of this transcription factor after $30 \mathrm{~min}$, pointining to the involvement of this gene in the osteogenesis induced by exposure to BMP2. Another essential gene related with osteoblastic differentiation is OSX, a transcription factor containing three zinc-fingers [45]. OSX was discovered as a BMPinduced gene in $\mathrm{C} 2 \mathrm{C} 12$ cells, with its deletion resulting in complete absence of osteoblasts in mouse embryos, despite the relatively normal expression of RUNX2 [39], which indicates that OSX is activated after RUNX2 during osteoblastic differentiation. In accordance, we observed that after a significant increase in RUNX2 after 30 min of 
induction, a consistent increase of mRNA OSX levels is observed up to $2 \mathrm{~h}$ after stimulus. Finally, we analized the expression levels of DLX-5, an homeobox gene that plays an essential role in craniofacial, axial, and appendicular skeletal development [46], and specifically regulates RUNX2 expression by binding to the homeodomain-response elements in the RUNX2 distal promoter [47]. The increased amounts of DLX-5 after exposure to BMP2 indicates that this gene is also present in our differentiation event, generating a reliable axis between DLX-5/RUNX-2/OSX.

\section{Novel phosphorylated candidates found upon BMP2 treatment of msMSCs}

From all three independent experiments, we chose proteins which displayed increased phosphorylation upon BMP2 treatment: a group of proteins related with cytoskeletal rearrangement and Ras protein signal transduction. Cytoskeletal rearrangement is observed during osteoblastic differentiation through the shift from a fibroblast-like to a spheric phenotype, upon induction with supplemented osteogenic differentiation medium (ODM), being antagonized by treatment with cytochalasin $\mathrm{D}$, leading to a reduction of differentiation markers expression [48]. Thus, catenin alpha 1, alpha parvin, septin-2, caldesmon, microtubule associated proteins $1 \mathrm{~B}$ and 4 , nexilin, cytoplasmic dynein 1 light intermediate chain and isoforms of lamin $\mathrm{A} / \mathrm{C}$ and plectin 1 were found to be upregulated at all time periods studied. Together with the previous studies which had described activation of these proteins using ODM $[48,49]$, we found that these proteins were also activated upon BMP2 treatment. This may be explained by the fact that a common subset of proteins can be activated by both BMP2 and components of ODM, phosphorylating other proteins related which cytoskeletal rearrangement. Another protein related with cytoskeletal rearrangement found in our experiments was Rho GTPase-activating protein. The Rho family of GTPases plays an important role in osteoblastic differentiation, shown by differentiation to osteogenesis of constitutively RhoA-expressing mesenchymal stem cells [50]. Other proteins involving signaling pathways in osteoblastic differentiation were positively phosphorylated, namely: Transforming growth factor beta 1 induced transcript (Hic-5) and Bcl-2-associated transcription factor 1 displayed increasing phosphorylation levels. These proteins are related to the Wnt pathway and, specifically, Hic- 5 was involved in regulation of intracellular signals by Smad 1, 5 and 8, effector proteins of the canonical BMP2 signaling pathway [51].

\section{Conclusions}

Stable isotope dimethyl labeling of peptides may be used to quantify small amounts of proteins phosphorylated in cell extracts. During BMP2-induced differentiation in skin derived mesenchymal stem cells, it was possible to acess different proteins, which many of them were found to be phosphorylated in different timepoints, giving new cues about the events that occur in the short term of osteoblastic differentiation.

\section{Methods \\ Cell isolation}

The cells were isolated from BALB/C mice dermis through careful dissecation from skin and FACS sorting, being CD105+, CD73+, CD90+, lacking CD14 and CD34 as surface markers (more than $90 \%$ purity), being able to growth under plastic and differentiate into osteoblastic cells by osteodifferentiation-induced assay (ascorbic acid, beta-glycerolphosphate and dexamethasone) and AlizarinRed stainig after 14 and 21 days. These cells were also capable of chondro, osteo and adipogenesis, validated through histochemistry and gene expression assays (Forni et al., in preparation), as described in the literature [52].

\section{Materials}

The protease (Benzonase ${ }^{\odot}$ ) and phosphatase inhibitor cocktail (Complete ${ }^{\odot}$ ), were purchased from Roche (Mannheim, Germany). Modified porcine trypsin was purchased from Promega (Fitchburg, USA). DTT, ammonium bicarbonate, sodium cyanoborohydride, iodoacetamide, triethylammonium bicarbonate (TEAB) and glycolic acid, were from Sigma (Steinheim, Germany). $\mathrm{CD}_{2} \mathrm{O}$ (98\% D, 20 wt $\%),{ }^{13} \mathrm{CD}_{2} \mathrm{O}\left(99 \%{ }^{13} \mathrm{C}, 98 \% \mathrm{D}, 20 \mathrm{wt} \%\right)$, and sodium cyanoborodeuteride $(96 \%$ D) were from Isotec (Miamisburg, USA). Formaldehyde (37\%) and ammonia solution (25\%) was purchased from Merck (Darmstadt, Germany). Poros Oligo R3 reversed-phase material was from PerSeptive Biosystems (Framingham, USA). TiO2 beads were obtained from GL Science (Tokyo, Japan). EmporeTM C8 extraction disk was from $3 \mathrm{M}$ Bioanalytical Technologies (St Paul, USA). The water used in all experiments was obtained from a Milli-Q purification system (Millipore, USA). All other chemicals were purchased from commercial sources and were of analysis grade.

\section{Total protein extract from murine-derived mesenchymal stem cells induced with rhBMP2}

Cell extracts from mesenchymal stem cells were made as previously described [53], with some modifications. Briefly, murine skin-derived mesenchymal stem cells (msMSC) obtained in our laboratory, were seeded onto $100 \mathrm{~mm}$ diameter culture plate in Dulbecco's modified Eagle's Medium (DMEM) containing GlutamaxI (Life Technologies, USA), 1\% penicillin/streptomycin (Life Technologies, USA) and 10\% fetal bovine serum (Life Technologies, USA) at $37^{\circ} \mathrm{C}$ until they reached $90 \%$ confluence. The medium was then changed in each experimental group (10 min, $30 \mathrm{~min}, 1 \mathrm{~h}$ and $2 \mathrm{~h}$ ) for DMEM 
supplemented with $200 \mathrm{ng} / \mathrm{ml}$ of rhBMP2 (Life Technologies, USA) and 10\% fetal bovine serum. After the induction period, the cultures were washed twice with ice-cold PBS buffer. After washing, cells were harvested and the cell suspension was then centrifuged at 1,000 g for $5 \mathrm{~min}$. The cell pellet was ressuspended in $100 \mu \mathrm{l}$ of lysis buffer (7 M urea (Sigma, Steinheim, Germany), $2 \mathrm{M}$ thiourea (Merck), 1\% N-octyl glycoside (Sigma, Steinheim, Germany), $40 \mathrm{mM}$ Tris (Sigma, Steinheim, Germany) containing phosphatase and proteinase inhibitors (PhosStop and Complete - Roche) and 300 units of Benzonase (Merck). The cells were then sonicated at $40 \%$ output with intervals of $3 \times 15 \mathrm{~s}$ on ice to disrupt the cells and then incubated at $-80^{\circ} \mathrm{C}$ for $30 \mathrm{~min}$. After incubation, $20 \mathrm{mM}$ DTT was added, and samples were incubated at room temperature for $35 \mathrm{~min}$. Iodoacetamide $(40 \mathrm{mM})$ was then added, followed by incubation for $35 \mathrm{~min}$ at room temperature in the dark. For protein precipitation, $14 \mathrm{ml}$ of ice-cold acetone was added to the solution, followed by incubation at $-20^{\circ} \mathrm{C}$ for $20 \mathrm{~min}$. The proteins were pelleted by centrifugation at $6,000 \mathrm{~g}$ for $10 \mathrm{~min}$ at $4^{\circ} \mathrm{C}$, and the pellet was stored at $-20^{\circ} \mathrm{C}$ until further use. The BCA method was used to determine the protein concentration of each sample.

\section{Tryptic digestion of total protein extracts}

Precipitated proteins from msMSC cells were solubilized in $100 \mathrm{mM} \mathrm{TEAB}$, and $50 \mu \mathrm{g}$ of total protein extract, quantified by the bicinchoninic acid assay kit (Pierce, Waltham, USA), incubated with chemically modified trypsin at a proportion of 1:100, and subsequently incubated at room temperature for $18 \mathrm{~h}$.

\section{R3 microcolumns for desalting}

The Poros Oligo R3 reversed phase resin was suspended in $70 \%$ acetonitrile. The R3 beads were loaded onto constricted GELoader (Eppendorf, Hamburg, Germany) tips containing a $\mathrm{C}_{8}$ microdisc and gentle air pressure was applied to pack the beads in order to obtain R3 microcolumns of $3 \mathrm{~mm}$ [54]. Each acidified sample was loaded onto an R3 microcolumn. The R3 microcolumns were subsequently washed with $30 \mu \mathrm{l}$ of $0.1 \%$ TFA, and the peptides were eluted from the Poros R3 column using $30 \mu \mathrm{l}$ of $70 \%$ acetonitrile, $0.1 \%$ TFA. The phosphopeptides were subsequently ressuspended in $0.5 \mu \mathrm{l}$ of $100 \%$ formic acid and $10 \mu \mathrm{l}$ of $(0.1 \%$ formic acid) prior to nanoLC-MS analysis.

\section{Dimethyl labeling}

After digestion, the total protein extract was quantified by the BCA method and the volume was adjusted to $100 \mu \mathrm{l}$ of $100 \mathrm{mM}$ TEAB. $\mathrm{CH}_{2} \mathrm{O}(4 \mu \mathrm{l}, 4 \%$, "light") or $4 \%$ $\mathrm{CD}_{2} \mathrm{O}$ ("intermediate") or $4 \%{ }^{13} \mathrm{CD}_{2} \mathrm{O}$ ("heavy") was added, followed by the addition of $4 \mu \mathrm{l}$ of $600 \mathrm{mM} \mathrm{NaBH} \mathrm{N}_{3} \mathrm{CN}$ (light and intermediate) or $4 \mu \mathrm{l}$ of $600 \mathrm{mM} \mathrm{NaBD}{ }_{3} \mathrm{CN}$ (heavy). The mixture was incubated for $1 \mathrm{~h}$ at room temperature. The reaction was quenched with $16 \mu \mathrm{l}$ of $1 \%$ ammonia and $8 \mu \mathrm{l}$ formic acid was added. The differentially labeled samples from three different time points were pooled and desalted using microcolumns filled with Poros R3 beads. This sample was subjected to vacuum centrifugation and stored at $-20^{\circ} \mathrm{C}$ for further use.

\section{Titanium dioxide $\left(\mathrm{TiO}_{2}\right)$ chromatography}

The pooled samples were subjected to the phosphoenrichement procedure by mixing with $\mathrm{TiO}_{2}$ beads, which were ressuspended in loading buffer ( $1 \mathrm{M}$ glycolic acid in $80 \%$ acetonitrile, $5 \%$ TFA). $15 \mathrm{mg}$ of $\mathrm{TiO}_{2}$ beads (suspended in $100 \%$ acetonitrile) were washed in loading buffer and loaded into the sample tube. The mixture was incubated for $15 \mathrm{~min}$ at ambient temperature under agitation (150 rpm). The mixture was centrifuged for $60 \mathrm{~s}$ at $12,000 \mathrm{~g}$ and the supernatant was collected, dessalted, and lyophilized. The $\mathrm{TiO}_{2}$ beads, complexed with phosphopeptides, were washed twice with $500 \mu \mathrm{l}$ of loading buffer and, subsequently, with $30 \mu \mathrm{l}$ of washing buffer ( $80 \%$ acetonitrile, 5\% TFA). The phosphopeptides were eluted using $50 \mu \mathrm{l}$ of ammonium water $(\mathrm{pH}$ 11.3) followed by $10 \mu \mathrm{l}$ of $30 \%$ acetonitrile. The eluent was acidified by adding $5 \mu \mathrm{l}$ of $100 \%$ formic acid prior to the dessalting step.

\section{Offline TSK amide-80 HILIC peptide fractionation}

Peptide fractionation was performed using a neutral TSK Amide-80 HILIC ( $3 \mu \mathrm{m}$; Tosoh Bioscience, San Francisco, USA) and a mobile phase containing TFA. The purified peptides were ressuspended in $90 \%$ acetonitrile, $0.1 \%$ TFA and loaded onto a $320 \mu \mathrm{m}$ inner $/ 450 \mu \mathrm{m}$ outer diameter $\times$ $17 \mathrm{~cm}$ microcapillary column packed with TSK Amide-80 using an Agilent 1200 Series HPLC (Agilent, Santa Clara, USA). The HPLC gradient was $100-60 \%$ of solvent $90 \%$ acetonitrile/0.1\% TFA in water for $42 \mathrm{~min}$ at a flow-rate of $6 \mu \mathrm{L} / \mathrm{min}$. Fractions were collected every minute and combined into 8-12 fractions depending on the intensity of UV detection measured at $210.8 \mathrm{~nm}$. The fractions were dried by vacuum centrifugation.

\section{Nano-LC-MS}

Nano-LC-MS experiments were performed using a 7-tesla LTQ-FT mass spectrometer (Thermo Electron, Bremen, Germany). The sample was applied onto an EASY nanoLC system (Proxeon Biosystems, Odense, Denmark). The peptides were loaded onto an $18 \mathrm{~cm}$ analytical column (100 $\mu \mathrm{m}$ inner diameter/360 $\mu \mathrm{m}$ outer diameter, ReproSilPur C18 AQ $3 \mu \mathrm{m}$ (Dr. Maisch, Ammerbuch-Entringen, Germany), and eluted from the column using a gradient from $100 \%$ phase A (0.5\% acetic acid aqueous solution) to $40 \%$ phase B (0.5\% acetic acid, $80 \%$ acetonitrile) in $113 \mathrm{~min}$ 
at $45 \mathrm{nl} / \mathrm{min}$. The instrument was operated in a datadependent mode automatically switching between MS, $\mathrm{MS}^{2}$, and $\mathrm{pdMS}^{3}$ [55]. The top 10 parent ions of the spectra were chosen for fragmentation. The pdMS ${ }^{3}$ acquisition was set to automatically select and further fragment the fragment ion originating from the loss of phosphoric acid from the parent ions (standard pdMS3 settings).

\section{Database analysis}

The ".raw" MS data were processed using the ThermoProteome Discoverer software (Thermo Electron, Bremen, Germany). The generated ".mgf" files were subsequently searched against the murine sequence library in the International Protein Index (IPI) protein sequence database (IPI mouse v3.77) using an in-house Mascot server (version 2.1) (Matrix Science Ltd. London, UK). The search was performed by choosing trypsin as the enzyme with two miss-cleavages allowed. Carbamidomethyl (Cys), dimethyl labeling for light, medium and heavy modifications of N-terminus and Lys $(+28,+32$ and $+36 \mathrm{Da}$, respectively) were chosen as the fixed modification. As variable modifications, oxidations (Met) and phosphorylation (Serine, Threonine and Tyrosine, S,T,Y), were chosen. The data were searched with a peptide mass tolerance of $10 \mathrm{ppm}$ and a fragment mass tolerance of $0.8 \mathrm{Da}$. A concatenated decoy database search was performed in a concatenated decoy mouse database (IPImousedecoy) derived from the IPI mouse database listed above for each of the conditions, and only peptides with up to $1 \%$ of False Discovery (FDR) were selected. Dimethyl quantification was performed using Thermo Proteome Discoverer (v1.1) from the extracted chromatograms (XIC's) obtained. Normalization was achieved using the LOWESS fitting algorithm [24] and protein grouping and statistics were obtained using StatQuant [56]. The phosphopeptide subpopulation were compared to a databasis consisting of motifs for phosphorylation by different kinases in NetworKIN website (http://www.networkin. info/version_2_0/) [57]. Non-phosphorylated population of peptides were classified according to biological process using the Gene Ontology software Blast2go [58] (http://www.blast2go.com). Ingenuity (Ingenuity Systems, Redwood City, USA) was used to investigate protein network interactions. TRED (http://rulai.cshl. edu/cgiin/TRED/tred.cgi/process=home) was used to search for gene targets for transcription factors and JASPAR (http://129.177.120.189/cgibin/jaspar2010/ jaspar_db.pl) was used to check for transcription factor binding motifs.

\section{Total mRNA extraction and purification from} rhBMP2-induced msMSC cells

$3.10^{4}$ / cells per $\mathrm{ml}$ were seeded onto $100 \mathrm{~mm}$ diameter culture plate. After treatment with rhBMP2 (Life Technologies,
USA) for different time periods, cells were washed with ice-cold PBSA, and total mRNA was isolated using silica columns from the RNeasy ${ }^{\oplus}$ mini-kit (Qiagen, Hilden, Germany). The mRNA concentration was determined by absorbance at $260 \mathrm{~nm}$ and the purity of the preparations was evaluated by the $A_{260} \mathrm{~nm} / \mathrm{A}_{280} \mathrm{~nm}$ ratio, with purity being considered when this ratio was approximately 2.0 .

\section{cDNA synthesis}

Total cellular RNA, isolated as mentioned above, was used to synthetize the corresponding cDNA. An aliquot $(1 \mu \mathrm{g})$ of RNA from each condition was incubated with 2 units of DNase I (Thermo Fischer Scientific, Waltham, USA) and 20 units of RNAseOUT for $10 \mathrm{~min}$ at $37^{\circ} \mathrm{C}$. After this incubation period, both enzymes were heatinactivated for $10 \mathrm{~min}$ at $75^{\circ} \mathrm{C}$ and $1 \mu \mathrm{l}$ of $0.5 \mu \mathrm{g} / \mu \mathrm{l}$ of oligo-dT, $1 \mu \mathrm{l}$ of $10 \mathrm{mM}$ dNTP, were added. The samples were incubated for $10 \mathrm{~min}$ at $65^{\circ} \mathrm{C}$ and then immediately placed on ice. After addition of 200 units of SuperScript ${ }^{\oplus}$, $2 \mu \mathrm{l}$ of $100 \mathrm{mM}$ DTT and 20 units of RNAseOUT were added to each tube, samples were incubated for $10 \mathrm{~min}$ at $25^{\circ} \mathrm{C}$ for primer annealing, and then for $120 \mathrm{~min}$ at $50^{\circ} \mathrm{C}$ for cDNA synthesis. SuperScript ${ }^{\oplus}$ enzyme was heat-inactivated and the template RNA was then degraded upon incubation with 5 units of $\mathrm{RNaseH}$, for $30 \mathrm{~min}$ at $37^{\circ} \mathrm{C}$.

\section{Quantitative Real Ttime PCR (qRT-PCR)}

The experiments were carried out according to the MIQE guidelines [59]. The first step for the primer selections was to select from already published data a set of genes of interest differentially regulated during osteogenesis $[22,60]$. The primer sequences were then selected from a validated bank of oligos previously tested and approved for qRT-PCR, the PrimerBank [61]. The primer concentration was then optimized for each gene using a cDNA pool from different periods of time of treatment with BMP2, adopting the lowest primer concentration for each condition that did not interfere with the amplification curve inclination, in order to avoid nonspecific results derived from primer dimers. The qRT-PCR reaction was carried out using $6 \mu$ l the $\mathrm{SYBR}^{\oplus}$ Green Dye (Life Technologies, Carlsbad, USA), $3 \mu$ l of 30 times diluted cDNA and $3 \mu \mathrm{l}$ of a mix containing both the forward and the reverse primers (Table 3 ), and incubated under the following conditions: $2 \mathrm{~min}$ at $50^{\circ} \mathrm{C}, 10 \mathrm{~min}$ at $95^{\circ} \mathrm{C}$, followed by 40 cycles of 15 seconds at $95^{\circ} \mathrm{C}$ and $60^{\circ} \mathrm{C}$ for $1 \mathrm{~min}$. The data were collected and analyzed using the 7300 System Software (Life Technologies, Carlsbad, USA). The quality control of each reaction was achieved through a cycle of dissociation, in order to exclude possible crosscontaminations or the presence of dimers. To confirm the differential expression for each gene, the GeneAmp 5700 software was used, and the threshold was set to 0.1. The 
data was exported and interpreted using the $\mathrm{qBASE}^{\mathrm{PLUS2}}$ (Biogazelle, Zwijnaarde, Belgium). The first step was to use the Genorm [62] tool, a very popular algorithm that finds the stablest reference (housekeeping) genes from a set of tested candidate reference genes in a given experimental condition, in this case, GAPDH, HMBS and HPRT. From this, a gene expression normalization factor was calculated for each sample, based on the geometric mean of a user-defined number of the reference genes. After analysis, the data was exported and the graphic pictures and statistical analysis were performed using the GraphPad Prism 5 software (GraphPad Software, La Jolla, USA). The data presented in this work are representative of 3 independent experiments, performed in duplicates, and were analised through a one-way Anova followed by a post-test of Tukey with $\mathrm{p}<0.005$.

\section{Additional files}

Additional file 1: Phosphorylated peptides found in MS experiments. Acession number, delta score, retention area (for light medium and heavy labeled peptides) of phosphorylated peptides.

Additional file 2: Phosphorylated proteins found and relative ratio variation for different timepoints of BMP2-induction and calculated $p$-value for all peptides corresponding to a specific protein. For a given accession number corresponding to a protein, a subset of peptides were found in MS experiments, and the ratio between each timepoint was calculated using StatQuant software according to the area of extracted chromatogram. Statistical analysis was calculated for a population of peptides corresponding to a same protein accession.

Additional file 3: Phosphorylated sites found in peptides according to MS experiments and kinase phosphorylation analysis using NetworkIN 2.0 Beta (http://www.networkin.info/version_2_0/). To investigate which kinases could be involved in the phosphorylation of peptides found in MS experiments, NetworKIN 2.0 Beta kinase databank was used to match phoshorylated serine, threonine and tyrosine in peptides found to be phoshorylated, according to prior experiments in literature for a given kinase based on PhosphoELM (http://phospho.elm. eu.org/) and on Phosphosite (http://www.phosphosite.org).

Additional file 4: Network of proteins which were found to interact with phosphorylated proteins found. The list of phosphoproteins found were subjected to Ingenuity Pathway Analysis (IPA) to investigate probable protein interactions for each cellular compartment. Proteins described to be transcription factors were selected to investigate the activation of osteoblast related genes by quantitative real-time PCR.

Additional file 5: Predicted network of interaction for phosphoproteins found using Ingenuity Pathway Analysis. Ingenuity Pathway Analysis was used to identify the network of proteins which could interact with the phosphoproteins identified. Dashed arrows represent the predicted interactions and the full arrows represent a confirmed interaction. Proteins were separated by cell compartment and proteins known to be transcription factors were selected to further analysis to investigate possible activators of osteoblast differentiation by real-time quantitative PCR.

Additional file 6: Motifs and Pre-selected genes used in RT-PCR experiments. The motifs listed were used to search for correspondents in the promoter region of the pre-selected genes. Those which displayed at least one match matches for the sequences (SP1, c-Myc e NF-kB) were selected for the GRT-PCR analysis.

\section{Authors' contributions}

EH carried out the sample preparation, mass spectrometry and data analysis and drafted the manuscript. MFF carried out the RT-PCR experiments and data analysis and also isolated the cell line used in this work. AF participated in the mass spectrometry data normalization. TVB supported stable isotope dimethyl labeling and mass spectrometry experiments. ONJ participated in the manuscript revision, and revised a. MCS conceived of the study, and participated in its design and coordination and helped to draft the manuscript. All authors read and approved the final manuscript.

\section{Acknowledgements}

We would like to thank Marc Sylvester for his invaluable advices regarding quantitative proteomics, Marcella Nunes de Melo Braga (University of Southern Denmark) for helping to set up the dimethyl labeling, Giuseppe Palmisano (Harvard University) and Melanie Schultz (University of Southern Denmark) for advices regarding sample analysis in MS sample preparation and data analysis. The excellent technical assistance of Zizi de Mendonça, Debora Costa Lopes and Marluce C. Mantovani is also acknowledged. This project was supported by: BNDES, CAPES, CNPq, FAPESP (grant number 2008/53974-4),MCTI and MS-DECIT.

\section{Author details}

'Chemistry Institute, Department of Biochemistry, Cell and Molecular Therapy Center (NUCEL/NETCEM), School of Medicine, University of São Paulo, São Paulo 05508-000, SP, Brazil. ²Department of Computer Science, Institute of Mathematics and Statistics, University of São Paulo, Rua do Matão 1010, São Paulo, SP 05508-090, Brazil. ${ }^{3}$ Department of Biochemistry and Molecular Biology, University of Southern Denmark, Odense, Denmark.

Received: 16 April 2013 Accepted: 9 October 2013

Published: 22 October 2013

\section{References}

1. Deschaseaux F, Sensébé L, Heymann D: Mechanisms of bone repair and regeneration. Trends Mol Med 2009, 15:417-429.

2. Deschaseaux F, Pontikoglou C, Sensebe L: Bone regeneration: the stem/ progenitor cells point of view. J Cell Mol Med 2010, 14:103-115.

3. García-Castro J, Trigueros C, Madrenas J, Pérez-Simón JA, Rodriguez R, Menendez P: Mesenchymal stem cells and their use as cell replacement therapy and disease modelling tool. J Cell Mol Med 2008, 12:2552-2565.

4. Driskell RR, Clavel C, Rendl M, Watt FM: Hair follicle dermal papilla cells at a glance. J Cell Sci 2011, 124(Pt 8):1179-1182.

5. Vaculik C, Schuster C, Bauer W, Iram N, Pfisterer K, Kramer G, Reinisch A, Strunk D, Elbe-Bürger A: Human dermis harbors distinct mesenchymal stromal cell subsets. J Invest Dermatol 2011, 132(3 Pt 1):563-74.

6. Fuentealba LC, Eivers E, Ikeda A, Hurtado C, Kuroda H, Pera EM, De Robertis EM: Integrating patterning signals: Wnt/GSK3 regulates the duration of the BMP/Smad1 signal. Cell 2007, 131:980-993.

7. Boersema PJ, Mohammed S, Heck AJR: Phosphopeptide fragmentation and analysis by mass spectrometry. J Mass Spectrom Jms 2009, 44:861-878.

8. Jensen ON: Interpreting the protein language using proteomics. Nat Rev Mol Cell Biol 2006, 7:391-403.

9. Larsen MR, Trelle MB, Thingholm TE, Jensen ON: Analysis of posttranslational modifications of proteins by tandem mass spectrometry. Biotechniques 2006, 40:790-798.

10. Larsen MR, Thingholm TE, Jensen $O N$, Roepstorff $P$, Jorgensen TJ: Highly selective enrichment of phosphorylated peptides from peptide mixtures using titanium dioxide microcolumns. Mol Cell Proteomics 2005, 4:873-886.

11. Posewitz MC, Tempst P: Immobilized gallium(III) affinity chromatography of phosphopeptides. Anal Chem 1999, 71:2883-2892.

12. Hsu J-L, Huang S-Y, Chow N-H, Chen S-H: Stable-isotope dimethyl labeling for quantitative proteomics. Anal Chem 2003, 75:6843-52.

13. Boersema PJ, Raijmakers R, Lemeer S, Mohammed S, Heck AJ: Multiplex peptide stable isotope dimethyl labeling for quantitative proteomics. Nat Protoc 2009, 4:484-494.

14. Steen $\mathrm{H}$, Jebanathirajah JA, Rush J, Morrice N, Kirschner MW: Phosphorylation analysis by mass spectrometry: myths, facts, and the consequences for qualitative and quantitative measurements. Mol Cell Proteomics 2006, 5:172-181. 
15. Savitski MM, Lemeer $S$, Boesche $M$, Lang M, Mathieson T, Bantscheff M, Kuster B: Confident phosphorylation site localization using the Mascot Delta Score. Mol Cell proteomics MCP 2011, 10:M110.003830.

16. Vlieghe D, Sandelin A, De Bleser PJ, Vleminckx K, Wasserman WW, Van Roy $F$, Lenhard B: A new generation of JASPAR, the open-access repository for transcription factor binding site profiles. Nucleic Acids Res 2006, 34(Database issue):D95-D97.

17. Schneider TD, Stephens RM: Sequence logos: a new way to display consensus sequences. Nucleic Acids Res 1990, 18:6097-6100.

18. Stormo GD: DNA binding sites: representation and discovery. Bioinformatics 2000, 16:16-23.

19. Wasserman WW, Sandelin A: Applied bioinformatics for the identification of regulatory elements. Nat Rev Genet 2004, 5:276-287.

20. Robertson G, Bilenky M, Lin K, He A, Yuen W, Dagpinar M, Varhol R, Teague K, Griffith OL, Zhang X, Pan Y, Hassel M, Sleumer MC, Pan W, Pleasance ED, Chuang M, Hao H, Li YY, Robertson N, Fjell C, Li B, Montgomery SB, Astakhova T, Zhou J, Sander J, Siddiqui AS, Jones SJM: cisRED: a database system for genome-scale computational discovery of regulatory elements. Nucleic Acids Res 2006, 34(Database issue):D68-D73.

21. Song CX, Wang FJ, Ye ML, Cheng K, Chen R, Zhu J, Tan YX, Wang HY, Figeys $D$, Zou HF: Improvement of the quantification accuracy and throughput for phosphoproteome analysis by a pseudo triplex stable isotope dimethyl labeling approach. Anal Chem 2011, 83:7755-7762.

22. Balint E, Lapointe D, Drissi H, van der Meijden C, Young DW, van Wijnen AJ, Stein JL, Stein GS, Lian JB: Phenotype discovery by gene expression profiling: mapping of biological processes linked to BMP-2-mediated osteoblast differentiation. J Cell Biochem 2003, 89:401-426.

23. Ulsamer A, Ortuño MJ, Ruiz S, Susperregui ARG, Osses N, Rosa JL, Ventura F: BMP-2 induces Osterix expression through up-regulation of Dlx5 and its phosphorylation by p38. J Biol Chem 2008, 283:3816-26.

24. Quackenbush J: Computational analysis of microarray data. Nat Rev Genet 2001, 2:418-427.

25. Cleveland WS: Robust locally-weighted regression and smoothing scatterplots. J Am Stat Assoc 1979, 74:829-836.

26. Fujita A, Sato JR, Rodrigues LDO, Ferreira CE, Sogayar MC: Evaluating different methods of microarray data normalization. BMC Bioinform 2006, 7:469.

27. Bragdon B, Thinakaran S, Moseychuk O, King D, Young K, Litchfield DW, Petersen NO, Nohe A: Casein kinase 2 beta-subunit is a regulator of bone morphogenetic protein 2 signaling. Biophys J 2010, 99:897-904.

28. Bragdon B, Thinakaran S, Moseychuk O, Gurski L, Bonor J, Price C, Wang L, Beamer WG, Nohe A: Casein kinase 2 regulates in vivo bone formation through its interaction with bone morphogenetic protein receptor type la. Bone 2011, 49:944-54.

29. Celil AB, Campbell PG: BMP-2 and insulin-like growth factor-I mediate Osterix (Osx) expression in human mesenchymal stem cells via the MAPK and protein kinase D signaling pathways. J Biol Chem 2005, 280:31353-9.

30. Huang Y, Lin J, Lin C, Su Y, Hung S: c-Jun N-Terminal Kinase 1 Negatively Regulates Osteoblastic Differentiation Induced by BMP-2 via Phosphorylation of Runx2 at Ser104. J Bone Miner Res 2012, 27:1093-105.

31. Liu H, Liu Y, Viggeswarapu M, Zheng Z, Titus L, Boden SD: Activation of cJun $\mathrm{NH}(2)$-terminal kinase 1 increases cellular responsiveness to BMP-2 and decreases binding of inhibitory Smad6 to the type 1 BMP receptor. J bone Miner Res Off J Am Soc Bone Miner Res 2011, 26:1122-1132.

32. Guicheux J, Lemonnier J, Ghayor C, Suzuki A, Palmer G, Caverzasio J: Activation of p38 mitogen-activated protein kinase and c-Jun- $\mathrm{NH} 2$ -terminal kinase by BMP-2 and their implication in the stimulation of osteoblastic cell differentiation. J Bone Miner Res Off J Am Soc Bone Miner Res 2003, 18:2060-2068.

33. Bellosta P, Masramon L, Mansukhani A, Basilico C: p21(WAF1/CIP1) acts as a brake in osteoblast differentiation. J bone Miner Res Off J Am Soc Bone Miner Res 2003, 18:818-826.

34. Waters KM, Liu T, Quesenberry RD, Willse AR, Bandyopadhyay S, Kathmann LE, Weber TJ, Smith RD, Wiley HS, Thrall BD: Network analysis of epidermal growth factor signaling using integrated genomic. Proteomic and phosphorylation data. PLOS One 2012, 7:e34515.

35. Chen G, Deng C, Li YP: TGF-beta and BMP signaling in osteoblast differentiation and bone formation. Int J Bio/ Sci 2012, 8:272-288.

36. Long F: Building strong bones: molecular regulation of the osteoblast lineage. Nat Rev Mol Cell Biol 2011, 13:27-38.
37. Komori T, Yagi H, Nomura S, Yamaguchi A, Sasaki K, Deguchi K, Shimizu Y, Bronson RT, Gao YH, Inada M, Sato M, Okamoto R, Kitamura Y, Yoshiki S, Kishimoto T: Targeted disruption of Cbfa1 results in a complete lack of bone formation owing to maturational arrest of osteoblasts. Cell 1997, 89:755-764.

38. Otto F, Thornell AP, Crompton T, Denzel A, Gilmour KC, Rosewell IR, Stamp GW, Beddington RS, Mundlos S, Olsen BR, Selby PB, Owen MJ: Cbfa1, a candidate gene for cleidocranial dysplasia syndrome, is essential for osteoblast differentiation and bone development. Cell 1997, 89:765-771.

39. Nakashima K, Zhou X, Kunkel G, Zhang Z, Deng JM, Behringer RR, De Crombrugghe $B$ : The novel zinc finger-containing transcription factor osterix is required for osteoblast differentiation and bone formation. Cell 2002, 108:17-29.

40. Bi W, Deng JM, Zhang Z, Behringer RR, De Crombrugghe B: Sox9 is required for cartilage formation. Nat Genet 1999, 22:85-89.

41. Ducy P, Starbuck M, Priemel M, Shen J, Pinero G, Geoffroy V, Amling M, Karsenty G: A Cbfa1-dependent genetic pathway controls bone formation beyond embryonic development. Genes Dev 1999, 13:1025-1036.

42. Guillot PV, De Bari C, Dell'Accio F, Kurata H, Polak J, Fisk NM: Comparative osteogenic transcription profiling of various fetal and adult mesenchymal stem cell sources. Differ Res Biol Divers 2008, 76:946-957.

43. Lindahl K, Barnes AM, Fratzl-Zelman N, Whyte MP, Hefferan TE, Makareeva E, Brusel M, Yaszemski MJ, Rubin C-J, Kindmark A, Roschger P, Klaushofer K, McAlister WH, Mumm S, Leikin S, Kessler E, Boskey AL, Ljunggren O, Marini JC: COL1 C-propeptide cleavage site mutations cause high bone mass osteogenesis imperfecta. Hum Mutat 2011, 32:598-609.

44. Bialek P, Kern B, Yang X, Schrock M, Sosic D, Hong N, Wu H, Yu K, Ornitz DM, Olson EN, Justice MJ, Karsenty G: A twist code determines the onset of osteoblast differentiation. Dev Cell 2004, 6:423-435.

45. Bandyopadhyay A, Tsuji K, Cox K, Harfe BD, Rosen V, Tabin CJ: Genetic analysis of the roles of BMP2, BMP4, and BMP7 in limb patterning and skeletogenesis. PLOS Genet 2006, 2:15

46. Robledo RF, Rajan L, Li X, Lufkin T: The Dlx5 and Dlx6 homeobox genes are essential for craniofacial, axial, and appendicular skeletal development. Genes Dev 2002, 16:1089-1101.

47. Lee M-H, Kim Y-J, Yoon W-J, Kim J-I, Kim B-G, Hwang Y-S, Wozney JM, Chi X-Z, Bae S-C, Choi K-Y, Cho J-Y, Choi J-Y, Ryoo H-M: Dlx5 specifically regulates Runx2 type II expression by binding to homeodomainresponse elements in the Runx2 distal promoter. J Biol Chem 2005, 280:35579-87.

48. Rodríguez JP, González M, Ríos S, Cambiazo V: Cytoskeletal organization of human mesenchymal stem cells (MSC) changes during their osteogenic differentiation. J Cell Biochem 2004, 93:721-731.

49. Lo T, Tsai C-F, Shih Y-R V, Wang Y-T, Lu S-C, Sung T-Y, Hsu W-L, Chen Y-J, Lee OK: Phosphoproteomic analysis of human mesenchymal stromal cells during osteogenic differentiation. J Proteome Res 2012, 11:586-598.

50. McBeath R, Pirone DM, Nelson CM, Bhadriraju K, Chen CS: Cell shape, cytoskeletal tension, and $\mathrm{RhoA}$ regulate stem cell lineage commitment. Dev Cell 2004, 6:483-495.

51. Shola DTN, Wang H, Wahdan-Alaswad R, Danielpour D: Hic-5 controls BMP4 responses in prostate cancer cells through interacting with Smads 1, 5 and 8. Oncogene 2011, 31:2480-2490.

52. Crigler L, Kazhanie A, Yoon T-J, Zakhari J, Anders J, Taylor B, Virador VM: Isolation of a mesenchymal cell population from murine dermis that contains progenitors of multiple cell lineages. FASEB J Off Publ Fed Am Soc Exp Biol 2007, 21:2050-2063.

53. Thingholm TE, Jensen ON, Robinson PJ, Larsen MR: SIMAC (sequential elution from IMAC), a phosphoproteomics strategy for the rapid separation of monophosphorylated from multiply phosphorylated peptides. Mol Cell Proteomics 2008, 7:661-671.

54. Gobom J, Nordhoff E, Mirgorodskaya E, Ekman R, Roepstorff P: Sample purification and preparation technique based on nano-scale reversedphase columns for the sensitive analysis of complex peptide mixtures by matrix-assisted laser desorption/ionization mass spectrometry. J Mass Spectrom 1999, 34:105-116.

55. Beausoleil SA, Jedrychowski M, Schwartz D, Elias JE, Villen J, Li J, Cohn MA, Cantley LC, Gygi SP: Large-scale characterization of HeLa cell nuclear phosphoproteins. Proc Natl Acad Sci U S A 2004, 101:12130-12135.

56. Van Breukelen B, van den Toorn HW, Drugan MM, Heck AJ: StatQuant: a post-quantification analysis toolbox for improving quantitative mass spectrometry. Bioinformatics 2009, 25:1472-1473. 
57. Linding R, Jensen LJ, Pasculescu A, Olhovsky M, Colwill K, Bork P, Yaffe MB, Pawson T: NetworkIN: a resource for exploring cellular phosphorylation networks. Nucleic Acids Res 2008, 36(Database issue):D695-D699.

58. Conesa A, Götz S, García-Gómez JM, Terol J, Talón M, Robles M: Blast2GO: a universal tool for annotation, visualization and analysis in functional genomics research. Bioinformatics 2005, 21:3674-6.

59. Bustin SA, Benes V, Garson JA, Hellemans J, Huggett J, Kubista M, Mueller R, Nolan T, Pfaffl MW, Shipley GL, Vandesompele J, Wittwer CT: The MIQE guidelines: minimum information for publication of quantitative realtime PCR experiments. Clin Chem 2009, 55:611-22.

60. Piek E, Sleumer LS, Van Someren EP, Heuver L, De Haan JR, De Grijs I, Gilissen C, Hendriks JM, Van Ravestein-van Os RI, Bauerschmidt S, Dechering $\mathrm{KJ}$, Van Zoelen EJ: Osteo-transcriptomics of human mesenchymal stem cells: accelerated gene expression and osteoblast differentiation induced by vitamin D reveals c-MYC as an enhancer of BMP2-induced osteogenesis. Bone 2010, 46:613-627.

61. Spandidos A, Wang X, Wang H, Seed B: PrimerBank: a resource of human and mouse PCR primer pairs for gene expression detection and quantification. Nucleic Acids Res 2010, 38(Database issue):D792-D799.

62. Etschmann B, Wilcken B, Stoevesand K, Von Der Schulenburg A, SternerKock A: Selection of reference genes for quantitative real-time PCR analysis in canine mammary tumors using the GeNorm algorithm. Vet Pathol 2006, 43:934-942.

doi:10.1186/1471-2121-14-47

Cite this article as: Halcsik et al.: New insights in osteogenic differentiation revealed by mass spectrometric assessment of phosphorylated substrates in murine skin mesenchymal cells. BMC Cell Biology 2013 14:47.

\section{Submit your next manuscript to BioMed Central and take full advantage of:}

- Convenient online submission

- Thorough peer review

- No space constraints or color figure charges

- Immediate publication on acceptance

- Inclusion in PubMed, CAS, Scopus and Google Scholar

- Research which is freely available for redistribution 